$3^{\text {rd }}$ of May 2012

\title{
Metal ions and amyloid fiber formation in neurodegenerative diseases. Copper, Zinc and Iron in Alzheimer's, Parkinson's and Prion disease
}

\author{
John H. Viles*
}

Queen Mary, University of London, School of Biological and Chemical Sciences, Mile End Road, London E1 4NS, UK

*Corresponding Author: E-mail: j.viles@qmul.ac.uk Tel: (44) 02078828443 Fax: (44) 02089830973

Running Head: Metal ions and amyloid fiber formation

Key words: misfolding; aggregation; structure; kinetics; synuclein, $\mathrm{A} \beta$, fibre

\begin{abstract}
Abbreviations: $A \beta$ Amyloid- $\beta$-peptide; $A D$, Alzheimer's disease; $C D$, Circular Dichroism; Nmethyl-D-aspartate receptors, NMDAR; Parkinson's disease, PD; Prion protein, PrP; $\alpha$ Synuclein, $\alpha$ Syn; ThT, Thioflavin T; transmissible spongiform encephalopathies, TSEs; TEM, Transmission Electron Microscopy.
\end{abstract}




\begin{abstract}
There are a group of diseases associated with protein misfolding and accumulation into amyloid fibers. Many of these diseases have a major impact on human health, in particular, Alzheimer's (AD), Parkinson's (PD) and Prion diseases. The focus of this review is to highlight how metal ions influence amyloid formation in a number of neurodegenerative diseases. Firstly, the various mechanisms by which metal ions might influence the kinetics of amyloid fiber formation are surveyed. The coordination of metal ions to a number of amyloidogenic proteins, with an emphasis on metal binding to intact fibers is reviewed. The kinetics of amyloid formation and the influence $\mathrm{Cu}^{2+}, \mathrm{Zn}^{2+}, \mathrm{Fe}^{3+}$ and $\mathrm{Ca}^{2+}$ have on amyloid-beta peptide $(\mathrm{A} \beta)$ fiber formation in $\mathrm{AD}$ is described in detail. The effect of metal ions on fibril formation for other amyloidogenic proteins, in particular $\mathrm{Cu}^{2+}$ binding to $\alpha$-synuclein ( $\alpha \mathrm{Syn}$ ) and the prion protein $(\operatorname{PrP})$, are also reviewed. The mechanism by which metal ions might influence neurotoxicity of amyloids is also discussed. Levels of metal ions found at the synapse are described and related to the affinity of metal ions for $\mathrm{A} \beta, \operatorname{PrP}$ and $\alpha \mathrm{Syn}$. In vivo evidence for a link between metal ions in these common neurodegenerative diseases, and the interplay between $\mathrm{A} \beta$ the prion protein and copper are reported. Finally, the possibility of a shared mechanism by which metal ions might influence amyloidosis is discussed.
\end{abstract}




\section{Contents}

1) Protein Misfolding diseases

2) How can metal ions induce protein misfolding and accumulation?

3) The relationship between fibers, oligomers and neurotoxicity

4) Amyloid fiber structure and metal ion coordination

4.1) $\mathrm{Cu}$-A $\beta$ structure:

4.2) $\mathrm{Cu}-\mathrm{PrP}$ structure:

4.3) $\mathrm{Cu}-\alpha \mathrm{Syn}$ structure:

4.4) Common feature of $\mathrm{Cu}^{2+}$ and $\mathrm{Zn}^{2+}$ coordination:

5) Kinetics of fiber formation:

5.1) Nucleation dependent polymerization

5.2) Monitoring Fiber Kinetics:

5.3) Growth Curve Analysis:

6) Metal ions and amyloid fiber formation in Alzheimer's disease

6.1) $\mathrm{Cu}^{2+}$ and $\mathrm{A} \beta$, amorphous aggregation versus fibrillization:

6.2 ) Mechanism of $\mathrm{Cu}^{2+}$ accelerated amyloid formation:

6.3) $\mathrm{Cu}$-A $\beta$ cell toxicity

6.4) $\mathrm{Zn}^{2+}-A \beta$, fiber inhibition, oligomer promotion

6.5) $F e^{3+}-A \beta$

6.6) $C a^{2+}-A \beta$

6.7) $A l^{3+}-A \beta$

7) Metal ions and amyloid formation in TSE

8) Metal ions and amyloid formation in Parkinson's disease

9) Metal ions and amyloid formation in other protein misfolding diseases

10) Metal ion homeostasis at the synapse and metal ion affinities for $A \beta$ and $\operatorname{Pr} P$ 10.1) $\mathrm{Cu}^{2+}$ and $\mathrm{Zn}^{2+}$ at the synapse

10.2) $\mathrm{Cu}^{2+}$ and $\mathrm{Zn}^{2+}$ affinities for $\mathrm{A} \beta$ and $\operatorname{Pr} P$

10.3) A $\beta$ toxicity mediated by copper bound $\operatorname{Pr} P^{C}$ at the synapse

11) Evidence for a link between metal ions and misfolding diseases:

11.1) $A D$

11.2) TSE

11.3) $P D$

12) Is there a shared metal ion associated mechanism amyloid formation?

13) Concluding remarks 


\section{1) Protein Misfolding Diseases}

Central to a number of neurodegenerative diseases and other diseases of protein accumulation and amyloidosis is the misfolding of individual proteins [1]. In Alzheimer's disease (AD), the most common form of dementia, a small 42 residue peptide, amyloid-beta peptide $(\mathrm{A} \beta)$, is cleaved from a larger amyloid precursor protein (APP). It is the accumulation of the A $\beta$ molecules into toxic oligomers and amyloid fibers that appears fundamental to the cascade of events, including the formation of neurofibrillary tangles of tau protein, central to the aetiology of AD dementia [2]. Similarly, in Parkinson's Disease (PD) the natively unstructured protein, $\alpha$-Synuclein ( $\alpha$ Syn), accumulates into $\beta$-sheet rich fibers within intra-cellular inclusion bodies, known as Lewy Bodies [3]. While misfolding of the mammalian prion protein (PrP) causes a group of transmissible spongiform encephalopathies (TSEs) in humans and other mammals [4]. The misfolding of the proteins triggers a cascade of events in these diseases, often including the accumulation of ordered fiber aggregates of these proteins, with amyloid structure rich in $\beta$ sheet [1]. Genetic alterations underlying familial forms of these diseases are associated with mutations or increased production of $\mathrm{A} \beta, \operatorname{PrP}$ and $\alpha \mathrm{Syn}$, indicating that these proteins play a central role in their respective diseases [3-5]. All three of these diseases have been linked to metal ion binding and changes in metal homeostasis $[6,7]$. Other protein misfolding diseases will be briefly discussed within this review because of their association with metal ions.

\section{2) How can metal ions induce protein misfolding and accumulation?}

The influence of metal ions on protein misfolding does not require an external environmental influence, simply a perturbation in metal ion homeostasis and compartmentalization [6-9]. The $\mathrm{Cu}^{2+}$ and $\mathrm{Zn}^{2+}$ ions are found concentrated within senile plaques of Alzheimer's disease patients directly bound to $\mathrm{A} \beta$ [10-13]. In PD, elevated levels of copper and iron ions have been reported in the cerebrospinal-fluid and Lewy bodies respectively $[14,15]$. In the case of the prion protein $\left(\mathrm{PrP}^{\mathrm{C}}\right), \mathrm{Cu}^{2+}$ ions are known to bind to in vivo and in vitro $[16,17]$ and influences prion protein levels in the brain [18]. Metal imbalance is an early charcteristic of prion disease [19] and $\mathrm{Cu}^{2+}$ has been found in scrapie isolates $\left(\mathrm{PrP}^{\mathrm{Sc}}\right)$ and confers prion strain type [20].

Concentration of these metal ions in amyloid fibers raises the possibility that these ions might trigger or promote amyloid formation. There are a number of ways the coordination of metal ions can influence fiber generation. These possible processes are illustrated in Figure 1. For example, the coordination might cause rearrangement of the protein main-chain and so trigger misfolding and subsequent protein accumulation, Figure 1 . $\mathrm{Cu}^{2+}$ binding to $\beta_{2}$-microglobulin 
$\left(\beta_{2} \mathrm{M}\right)$ has been shown to cause a key proline cis-trans isomerization, triggering misfolding and protein assembly in dialysis-related amyloidosis [21]. Coordination of the metal ion might involve inter-molecular cross-linking, Figure 1. Formation of dimers or high order oligomeric forms may again influence the protein misfolding and accumulation. For example, in vitro $\mathrm{Zn}^{2+}$ can form an inter-molecular complex with $\mathrm{A} \beta$, cross-linking between histidine residues on multiple $A \beta$ molecules, that inhibits fibrillization [22-24]. Coordination of a metal ion will typically affect the net charge of the protein, adding positive charge from the metal ion or losing charge from multiple deprotonation. As a consequence, a protein with an acidic pI may become more neutrally charged and therefore more prone to self-association. This mechanism is proposed to accelerate fiber formation kinetics when $\mathrm{Cu}^{2+}$ binds to $\mathrm{A} \beta$ [23]. Amyloid fibers are in equilibrium with monomeric and oligomeric forms; it is possible that the metal ions might stabilize the fibril or oligomers once formed, by for example, cross-linking via the metal ion. Alternatively, coordination of the metal ion could destabilize the normal non-pathogenic structure and so make misfolding more energetically favorable, Figure 1. This has been shown to occur when $\mathrm{Cu}^{2+}$ binds to the normal cellular form of the prion protein [25]. The fibril morphology might also be influenced by metal ions. $\mathrm{Fe}^{3+}$ ions have been shown to influence the morphology and toxicity of $\mathrm{A} \beta$ fibers [26] while $\mathrm{Cu}^{2+}$ influences prion strain type [20].

Furthermore, coordination of redox active metal ions, such as copper and iron might also influence protein accumulation by metal catalyzed chemical modification of the protein. For example, reactive oxygen species (ROS) have been shown to generate an $A \beta$ dimer by covalent cross-linking of tyrosine residues within $\mathrm{A} \beta$ [27]. Oxidation of the methionine and histidine residues have been reported for both $\mathrm{A} \beta$ and $\operatorname{PrP}[28,29]$. The majority of the methionine in $\mathrm{A} \beta$ (Met35) is oxidized within amyloid plaques [10]. While a large proportion of isolated scrapie (misfolded) prion protein is known to contain methionine residues oxidized to methionine-sulphoxide [30]. The chemical modification will in turn influence the stability, fiber forming kinetics and structure of the protein.

\section{3) The relationship between fibers, oligomers and neurotoxicity}

Initially mature amyloid fibers found in $\mathrm{AD}$ patients were identified as the neurotoxic entity in AD pathology, this concept was modified when it was found that small diffusible oligomers of $\mathrm{A} \beta$, rather than mature amyloid fibers were the more toxic form [31-33]. However a role for fibers in $A \beta$ neurotoxicity should not be ignored, as there remains strong evidence suggesting amyloid plaques, or possibly intermediates of the $A \beta$ fibrils, play a critical role $[34,35]$. Small 
oligomers rather than mature fibrils have also been highlighted as the most neourotoxic form for a number of other misfolding diseases [36]. Protein oligomers may be precursors to fiber formation but may also arise from fiber fragmentation [37]. Studying oligomers is extremely challenging as they tend to form heterogeneous mixtures and are often transient in nature. The toxic oligomers may share the same structural features as larger fibers, the increased toxicity may simply arise from an increase in the number of toxic elements per total protein mass [37]. A range of oligomeric forms have been identified with various structural features and oligomer sizes, which can be classified into pre-fibrilar oligomers, fibrillar oligomers and anular protofibrils using their antibody binding properties [33]. These oligomers can be on or off the pathway to fibers, in addition not all oligomers are cytotoxic. Both fibers and oligomers require the self-association of protein, thus factors that affect fibrillisation will also influence oligomer generation. Furthermore, amorphous aggregates, oligomers and fibers are all in equilibrium with the monomeric protein, thus stabilization or destabilization of one will perturb levels of the other. The equilibrium set-up between different forms is illustrated in Figure 2.

Although it may be that oligomers are the most toxic to cells, it appears that the rate of fibril formation in vitro can be strongly correlated with rates of disease progression in patients and animal models of the disease. This may be because conditions that promote amyloid formation also promote oligomers. For example, the familial early onset $\mathrm{AD}$, associated with $\mathrm{A} \beta$ mutations (E22K/G/Q) show considerably accelerated fibril growth times relative to the wildtype sequence [38]. Furthermore, the disease associated $\mathrm{A} \beta(1-42)$ is much more prone to rapidly forming fibers than $\mathrm{A} \beta(1-40)$. Similarly, mutations in $\alpha$ Syn associated with familial PD cause accelerated kinetics of fiber formation [39].

Despite significant progress in identifying misfolding proteins as central to the aetiology of a number of neurodegentrative diseases, the mechanism by which misfolded proteins are toxic is still not well established. The toxic action of may be intracellular, disrupting the mitochondrial membrane for example [32]. However, one popular hypothesis involves oligomers and fibers acting on the outer plasma membrane surface to disrupt membrane integrity [32]. The growing ends of fibers with exposed hydrophobic residues may be the region that perturbs membrane integrity. Furthermore, reactive oxygen species (ROS) generated at the membrane can cause lipid per-oxidation to further compromise the membrane [40]. The enhanced cytotoxic effects of $\mathrm{Cu}^{2+}$ bound to $\mathrm{A} \beta$ might be explained by concentrating redox active $\mathrm{Cu}^{2+}$ ions at the plasma membrane surface where they will generate harmful ROS [23, 41]. A recent study has 
highlighted the role for $\operatorname{PrP}^{\mathrm{C}}$ in mediating $\mathrm{A} \beta$ neuronal toxicity and describes how copper influences this process [42]; for more details see section 10.3.

\section{4) Amyloid fiber structure and metal ion coordination}

Amyloid fibers are typically un-branched fibers 7-12 nm thick and many microns long with a high proportion of $\beta$-sheet structure. The beta strands stack perpendicular to the long axis of the fiber forming intermolecular hydrogen bonds, this type of structural motif is known as a crossbeta structure. A range of biophysical methods have been applied to studying the structure of fibers. They include, X-ray fiber diffraction, solid-state NMR, cryo-EM, deuterium exchange and EPR of spin labels. The biophysical approaches and structural features of various amyloids have been reviewed [43-45]. The morphology of fibers and consequently their pathology can vary depending on the conditions in which the fibers form, metal ions will affect the morphology or 'strain' of fibers [20,26].

The coordination of metal ions to a number of amyloidogenic proteins have been studied extensively. For recent reviews in the area of $\mathrm{A} \beta$, see [46-49], for the prion protein $[50,51]$ and for $\alpha$ Syn [52].

4.1) $C u^{2+}-A \beta$ structure: $\mathrm{Cu}^{2+}$ binding to $\mathrm{A} \beta$ shows that one mole equivalent of $\mathrm{Cu}^{2+}$ bound to monomeric or mature $\mathrm{A} \beta$ fibers have identical coordination geometries $[53,54]$ and affinities [53]. The $\beta$-pleated core of $\mathrm{A} \beta$ fibers occurs between residues 14 to $40, \mathrm{Cu}^{2+}$ coordinating ligands falls just on the edge of this region. Solid-state NMR of the $\mathrm{Cu}^{2+}$ complex suggests that the fibrillar structure is not disrupted by $\mathrm{Cu}^{2+}$ coordination [55], figure 3 . The $\mathrm{A} \beta$ peptide contains three histidine residues $\left(\mathrm{His}^{6}, \mathrm{His}^{13}\right.$, His ${ }^{14}$ ), which along with the N-terminal amino group and aspartate form a tetragonal complex with $\mathrm{Cu}^{2+}$ ions $[53,54,56-64]$. A considerable amount of effort has been devoted to understanding the coordination geometry of $\mathrm{Cu}^{2+}$ bound to $A \beta$ and is the subject of a number of reviews [46-48]. Some of the details of the complex are yet to be agreed upon, and the model shown in Figure 3 [53] is only one of a number related structures suggested in the recent literature. A dynamic view of the $\mathrm{Cu}^{2+}$ complex involving imidazole coordination in both the axial and equatorial plain has now emerged [53, 57, 64, 65]. A numbers of interchangeable $\mathrm{Cu}^{2+}$ complexes from with related coordination geometries and different histidine sidechains in the equatorial plain and $\mathrm{pH}$ effecting their relative distribution $[53,57,64,65]$. 
4.2) $C u$ - $\operatorname{Pr} P$ structure: Less well understood is $\mathrm{Cu}^{2+}$ binding to the fibrillar form of PrP. Models of recombinant PrP amyloid fibers suggest that the core residues forming $\beta$-strands within PrP are between residues 160-225 [66, 67]. Thus in amyloid fibers the $\mathrm{Cu}^{2+}$ binding Nterminal residues (23-126) remain unstructured and may well bind $\mathrm{Cu}^{2+}$ with a similar coordination geometry as the cellular mammalian PrP, but this remains to be established.

Metal binding, $\mathrm{Cu}^{2+}$ in particular, has been studied extensively for the cellular monomeric prion protein, $\mathrm{PrP}^{\mathrm{C}}$. As many as six $\mathrm{Cu}^{2+}$ ions coordinate to the natively unstructured $\mathrm{N}$-terminal half of mammalian $\operatorname{PrP}^{\mathrm{C}}$ at physiological $\mathrm{pH}$. The structured $\mathrm{C}$-terminal domain of $\operatorname{PrP}^{\mathrm{C}}$ does not affect $\mathrm{Cu}^{2+}$ coordination, as its removal does not affect binding to the natively unstructured $\mathrm{N}$ terminal domain, $\operatorname{PrP}(23-126)$ [16]. $\mathrm{Cu}^{2+}$ loads onto full-length $\operatorname{PrP}^{\mathrm{C}}$ sequentially; the first equivalents of $\mathrm{Cu}^{2+}$ bind to the amyloidogenic region of $\operatorname{PrP}^{C}$, residues 90-126, followed by binding to the octarepeat region, residues 58-91 [16]. There are various binding modes, all involve tetragonal coordination to one or more histidine imidazole nitrogens.

PrP contains a repeating motif of eight amino acids, between residues 58 and 91, with each repeat containing a histidine residue. This highly conserved region binds up to four $\mathrm{Cu}^{2+}$ ions with identical coordination geometry $[68,69]$, Figure 3. A crystal structure of the $\mathrm{Cu}^{2+}$ bound octarepeat motif (residues HGGGW) indicates square-pyramidal geometry [70] involving coordinating nitrogen and oxygen ligands from the main-chain as well as the imidazole sidechain. A more complete picture of the modes of $\mathrm{Cu}^{2+}$ coordination shows that at substoichiometric levels, $\mathrm{Cu}^{2+}$ ions will bind with a higher affinity to the octarepeats via multiple histidine residues [71-74], Figure 3.

$\mathrm{Cu}^{2+}$ ions binding outside the octarepeat region are centered at $\mathrm{His}^{95}$ and $\mathrm{His}^{110}$ (His ${ }^{96}$ and His $^{111}$ in the human sequence) [75-84]. A square-planar/tetragonal complex is formed upon $\mathrm{Cu}^{2+}$ binding, which involves the histidine imidazole nitrogen $\delta \mathrm{N}$ and the main-chain amides that precede the histidine $[79,80]$, Figure 3. This type of complex is similar to that in the octarepeats but is more stable because it involves a six membered chelate ring to the imidazole nitrogen rather than seven, Figure 3. There is reasonable agreement in the literature regarding the $\mathrm{Cu}^{2+-} \mathrm{PrP}$ binding modes. The coordination geometries shown in Fig $3 \mathrm{~b}$ may be a simplification of the coordination modes, as with the $\mathrm{Cu}-\mathrm{A} \beta$ complex a number of related complexes may form interchangeably and their relative abundance will depend on the $\mathrm{pH}$ and levels of $\mathrm{Cu}^{2+}$. Indeed sub-stoichometric $\mathrm{Cu}^{2+}$ and lower $\mathrm{pH}$ values favor multiple histidine sidechain coordination $[16,71-74,80]$. Affinity measurements place the $\mathrm{K}_{d} \mathrm{~s}$, at $\mathrm{pH} 7.4$, for 
$\mathrm{Cu}^{2+}$ binding in the amyloidogenic region and octarepeats (multiple histidine binding mode) at $30 \mathrm{nM}$, tighter than $\mathrm{Cu}^{2+}$ binding to individual octa-repeats (90 nM) [85]. Although, others have reported tighter binding in the multiple His binding mode [71-73], suggesting $\mathrm{Cu}^{2+}$ will bind here first rather than concomitantly with $\mathrm{Cu}^{2+}$ binding centered at $\mathrm{His}^{110}$ [16].

4.3) $\mathrm{Cu}-\alpha \mathrm{Syn}$ structure: $\alpha \mathrm{Syn}$ is largely found in presynaptic terminals in the reducing environment of the csytosol, here $\alpha$ Syn will experience $\mathrm{Cu}^{+}$. There have been some studies of $\mathrm{Cu}^{+}$coordination to $\alpha$ Syn [86]. However, a proportion of $\alpha$ Syn is found extra-cellularly, secreted by neuronal cells $[87,88]$, and so $\mathrm{Cu}^{2+}$ binding may also be relevant and has been studied more extensively. The coordination geometry and affinity of $\mathrm{Cu}^{2+}$ ions to $\alpha$ Syn has been characterized by a number of groups. A range of spectroscopies including absorption, visible-CD and EPR has been used to characterize the coordination geometry [89]. While the paramagnetic broadening effects of $\mathrm{Cu}^{2+}$ has been studied using solution NMR [90]. Redox properties and coordination of the synuclein family of proteins have also been described [91, 92]. EPR and pulsed EPR methods have been used to carefully characterize the $\mathrm{Cu}^{2+}$ coordination to full-length natively unstructured $\alpha \operatorname{Syn}[93,94]$. It seems clear the main locus of binding to $\alpha$ Syn is at the N-terminal amino group. At $\mathrm{pH} 7.4$, two related tetragonal complexes dominate, with almost equal affinity. Both modes of coordination involve the Nterminal amino-group and the amide main-chain nitrogen and carboxylate side coordination from aspartate (Asp) at position 2. Mode 1 is indicative of $2 \mathrm{~N} 2 \mathrm{O}$ ligands ( Mode $1: \mathrm{NH}_{3}, \mathrm{~N}_{\text {amide }}$ $\mathrm{C}_{\beta} \mathrm{COO}$, and water) while Mode 2 is more indicative of $3 \mathrm{~N} 1 \mathrm{O}$ ligands and may possibly contain an imidazole nitrogen His51 to form a macrochelate to replace water coordination (Mode 2: $\mathrm{NH}_{3}, \mathrm{~N}_{\text {amide }}, \mathrm{C}_{\beta} \mathrm{COO}$, Hisimd) [93-95]. Recently a related $\mathrm{Cu}^{2+}$ complex is described at pH 6.5 [96]. The affinity for $\alpha$ Syn is 0.1-0.4 nanomolar [94, 97, 98] while other metal ions have weaker $\mathrm{mM}$ affinities for $\alpha \operatorname{Syn}[99]$. It is notable that the formation of amyloid fibers of $\alpha$ Syn may not restrict $\mathrm{Cu}^{2+}$ coordination centered at the $\mathrm{N}$-terminal amino group.

4.4) Common feature of $\mathrm{Cu}^{2+}$ and $\mathrm{Zn}^{2+}$ coordination: A feature of all three of these $\mathrm{Cu}^{2+}$ binding proteins is that the binding region is natively unstructured, thus the coordination site is not preformed but there is a structural rearrangement as the $\mathrm{Cu}^{2+}$ binds to the protein. All involve at least one imidazole nitrogen to form a tetragonal complex. A feature of $\operatorname{PrP}$ and $\alpha$ Syn is main-chain amide coordination to the $\mathrm{Cu}^{2+}$, which makes these binding sites quite specific to $\mathrm{Cu}^{2+}$ ions as few other metal ions are capable of amide deprotonation [79, 80, 100]. $\mathrm{Zn}^{2+}$ binding to proteins does not typically mimic the $\mathrm{Cu}^{2+}$ coordinating ligands. In particular, 
$\mathrm{Zn}^{2+}$ is not able to coordinate amide main-chain nitrogen. In addition, $\mathrm{Zn}^{2+}$ ions form tetrahedral complexes rather than tetragonal. There is evidence of $\mathrm{Zn}^{2+}$ causing inter-molecular cross-linking of imidazoles within $\mathrm{A} \beta$ molecules and multiple His imidazole coordination from the octarepeats of $\operatorname{PrP}[22,46,63,101]$.

\section{5) Kinetics of fiber formation:}

\section{1) Nucleation-dependant polymerization:}

The kinetics of amyloid fiber formation are often described as a nucleation-dependant polymerization reaction [1]. This process involves the protein monomer forming a nucleating 'seed', this is then followed by a more rapid self-templated growth where the ends of existing fibers recruit protein monomer and so extend fiber length. There is still debate as to the precise nature of the minimal form of protein that nucleates fiber formation. Suggestions range from misfolded monomeric species, dimer, penta to larger oligomers.

In vitro, the kinetics of fiber formation typically follows a sigmoidal fiber growth curve, Figure 4 [44, 102]. Key observables include the lag-phase (nucleation) and the maximal growth rate (elongation). Fiber growth then plateaus, reaching equilibrium with low amounts of monomer, known as the critical concentration of fiber formation. A key feature of the nucleationdependant polymerization reaction, is the ability of small amounts of pre-formed fibrils to 'seed' the reaction reducing the lag-phase significantly, Figure 4.

It is well established in vitro that kinetics of fiber formation are also often strongly influenced by agitation or sonication, which will cause significant fragmentation of fibers. It is now clear that a secondary nucleation process, in particular fragmentation, can significantly reduce the observable lag-time. The fragmentation-assisted growth has the effect of self-seeding fibril formation and can dominate the kinetics of fibril growth [103].

\section{2) Monitoring Fiber Kinetics:}

There are various methods by which the kinetics of fiber formation can be monitored in-vitro [102] . These include measuring a change in structure as $\beta$-sheets form within the fiber (via, for example, $\mathrm{CD}$ ) or change in particle size via dynamic light scattering. A common approach is to use fiber specific dyes. In particular, Thioflavin T (ThT) which when bound to amyloid fibers fluoresces at $487 \mathrm{~nm}$ [102]. This fluorescence signal is directly related to the amount of amyloid present. The kinetics of fiber growth are very sensitive to a number of factors such as $\mathrm{pH}$, concentration, agitation, temperature and ionic strength, these must be carefully controlled 
in vitro for direct comparisons. Solubilisation of the protein or peptide into a seed-free form is also important. Typically, a fluorescence well-plate reader is used for the ThT measurements so that repeat fiber growth measurements can be made under identical conditions for a direct comparison.

\section{3) Growth Curve Analysis:}

The fiber growth curve, Figure 4, can provide a number of empirical parameters, these including lag-time $\left(\mathrm{t}_{\mathrm{lag}}\right)$, the apparent rate of elongation $\left(\mathrm{k}_{\mathrm{app}}\right)$ and the time taken to reach half maximal fibre intensity $\left(\mathrm{t}_{50}\right)$. The fiber growth curve can be fitted to the following equation [104].

$$
\begin{aligned}
& \mathrm{Y}=\left(\mathrm{y}_{\mathrm{i}}+\mathrm{m}_{\mathrm{i}} \mathrm{x}\right)+\underline{\left(\mathrm{v}_{\mathrm{f}}\right.} \underline{\left.\underline{\mathrm{m}_{\mathrm{f}}} \underline{\mathrm{x}}\right)} \\
& \left(1+\exp ^{-(\mathrm{X}-\mathrm{Xo} / \tau)}\right)
\end{aligned}
$$

Where $\mathrm{Y}$ is the fluorescence intensity, $\mathrm{x}$ is the time and $\mathrm{X}_{0}$ is the time at half height of fluorescence $\left(t_{50}\right)$. The $k_{\text {app }}$ and $t_{\text {lag }}$ can be obtained from $1 / \tau$ and $X_{0}-2 \tau$ respectively. Others have obtained alternative empirical parameters [105] and a set of master equations to describe the kinetics of fiber formation have been proposed [103].

\section{6) Metal ions and $\mathrm{A} \beta$ fiber formation in $\mathrm{AD}$}

\section{1) $\mathrm{Cu}^{2+}$ and $\mathrm{A} \beta$, self-association, amorphous aggregation versus fibrillization:}

Two studies over a decade ago showed that $\mathrm{Zn}^{2+}$ and $\mathrm{Cu}^{2+}$ ions caused marked aggregation of the $\mathrm{A} \beta$ peptide [106-108]. However, these initial studies did not make the distinction between amorphous aggregates, which are thought to be non-toxic to cells, and the formation of amyloid fibers. Further investigations using the fiber specific fluorophore, thioflavin $\mathrm{T}$ (ThT), suggested that $\mathrm{Cu}^{2+}$ and $\mathrm{Zn}^{2+}$ only promote amorphous aggregation of $\mathrm{A} \beta$ and actually inhibit fiber formation [109-113]. Some of the confusion and misunderstanding in the literature surrounding the area can largely be attributed to using the word 'aggregation' and 'fibrillization' interchangeably. There are a number of studies now published that carefully characterize the promotion and nature of amorphous aggregates generated in the presence of $\mathrm{Cu}^{2+}[24,112-115]$. Studies using primary cell culture and immortal cell lines suggest $\mathrm{Cu}^{2+}$ induced amorphous aggregates are non-toxic to cells [109, 112]. 
In contrast to these studies, others have shown that at sub-stoichiometric levels of $\mathrm{Cu}^{2+}$ ions $\mathrm{A} \beta$ amyloid fiber formation is not inhibited, while supra-stoichiometric levels of $\mathrm{Cu}^{2+}$ ions promote amorphous aggregates, however the kinetics of fiber formation were not investigated $[27,116]$. A key study by Sarell et al showed that sub-stoichiometric levels of $\mathrm{Cu}^{2+}$ will actually significantly accelerate the kinetics of fiber formation, consistently reducing the lag-time of fiber formation of $A \beta(1-40)$ by more than half [23]. Figure 5 shows $A \beta$ fiber growth kinetics, metal-free $\mathrm{A} \beta$ preparations typically take more than $70+/-2$ hours to reach half maximal fluorescence $\left(\mathrm{t}_{50}\right)$, while the same $\mathrm{A} \beta$ preparations with 0.5 or 1 mole equivalent of $\mathrm{Cu}^{2+}$ ions cause fibers to form in nearly half the time; $38+/-2$ hours, at $\mathrm{pH}$ 7.4. The lag-time is reduced by $\mathrm{Cu}^{2+}$ ions, from 49 to 16 hours. Sub-stoichiometric amounts of $\mathrm{Cu}^{2+}$ between 0.2-0.4 mole equivalents display the greatest increase in fiber growth rates. This supports the hypothesis that $\mathrm{Cu}^{2+}$ accelerates nucleation as small sub-stoichiometric amounts of $\mathrm{Cu}^{2+}$ can nucleate fiber formation. Further addition of $\mathrm{Cu}^{2+}$ ions beyond one mole equivalent caused precipitation of $\mathrm{A} \beta$ and markedly reduces the amount of fibres generated [23], as previously noted [27, 116]. Furthermore, at high concentrations of $\mathrm{A} \beta(1-40)$ even sub-stoichiometric amounts of $\mathrm{Cu}^{2+}$ will inhibit fiber formation $[23,110,115]$. It is now clear that at sub-stoichiometric levels of $\mathrm{Cu}^{2+}$ to $\mathrm{A} \beta$ and more dilute concentrations of $\mathrm{A} \beta, \mathrm{Cu}^{2+}$ will accelerate the kinetics of fiber formation. While at supra-molecular levels of $\mathrm{Cu}^{2+}$ to $\mathrm{A} \beta$ or high concentrations of $\mathrm{A} \beta$ (40 micro-molar $\left.\mathrm{A} \beta_{40}\right)[23,115]$ fiber formation is inhibited. At these conditions, TEM and AFM studies indicate that amorphous aggregation is promoted at the expense of amyloid fiber formation $[24,112,113,115]$. Substoichiometric amounts of $\mathrm{Cu}^{2+}$ were also shown to promote $\mathrm{A} \beta(1-42)$ fiber formation [23], although others have not observed fiber inhibition under quite similar conditions [112]. $A \beta(1-42)$ is markedly less soluble than $A \beta(1-40)$ and so the completion favoring amorphous aggregation over fiber formation must be more pronounced. Table 1 highlights some of the studies performed investigating the effect of $\mathrm{Cu}^{2+}$ on $\mathrm{A} \beta(1-40)$ and $A \beta(1-42)$ fiber formation, highlighting the different effects of $\mathrm{Cu}^{2+}$ and $\mathrm{A} \beta$ concentrations.

The process of generating amyloid fibers (described as nucleation dependent polymerization) has many parallels with protein crystallization [1]. Like amyloid fibril formation crystallization can also be accelerated by a nucleating 'seed'. With protein crystallization, the concentration of the protein, the $\mathrm{pH}$ of the solution, and the levels of salts are adjusted to maximize selfassociation of the protein molecules into ordered crystals. If conditions are created that are too self-associating for the protein then amorphous aggregates are generated rather than crystals, 
this is also true in fibrillization; self-association must occur for ordered fibers to form, however, if conditions are too self-associating amorphous aggregates are generated.

The amorphous aggregates of $\mathrm{Cu}-\mathrm{A} \beta$ are not cytotoxic $[109,111,112]$, while $\mathrm{A} \beta$ preparations generated under sub-stoichiometric amount of $\mathrm{Cu}^{2+}$, that favor amyloid formation, will significantly enhance the cytotoxicity [23]. It seems clear that in vivo, levels of both A $\beta$ and $\mathrm{Cu}^{2+}$ are lower than for the in-vitro studies, thus $\mathrm{Cu}^{2+}$ is likely to exclusively accelerate fiber formation in-vivo.

\section{2) Mechanism of $\mathrm{Cu}^{2+}$ accelerated amyloid formation:}

So what is the mechanism by which $\mathrm{Cu}^{2+}$ ions accelerate the rate of fiber formation? A range of possible mechanisms by which metal ions might influence fiber formation kinetics are discussed in general terms in section 2. At micromolar concentrations of $\mathrm{A} \beta, \mathrm{Cu}^{2+}$ does not form crossed-linked species $[56,57,117]$. The $\mathrm{Cu}^{2+}$ coordination geometry is identical in the monomer and fiber [53, 54]. Most importantly, the affinity of $\mathrm{Cu}^{2+}$ for $\mathrm{A} \beta$ is identical for monomer and fiber, suggesting the same complex forms without cross-linking [53]. Furthermore, without a reductant there are no reactive oxygen species generated and therefore no di-tyrosine cross-linking [27], consequently copper bridging to form cross-linked $A \beta$, as a possible mechanism of accelerated fiber formation, is ruled out. The conformational changes in $\mathrm{A} \beta$ upon $\mathrm{Cu}^{2+}$ binding are small and outside of the fiber core [53, 56], it therefore seems unlikely that the $\mathrm{Cu}^{2+}$ coordination triggers the $\mathrm{A} \beta$ misfolding directly by a change in mainchain conformation. However, intermolecular self-association is strongly influenced by the net charge of the protein. As $A \beta$ approaches its isoelectric point, a pI of 5.3, and an overall neutral charge, its solubility decreases $[118,119]$. Furthermore, as the $\mathrm{pH}$ drops from 8 to 6 the rate at which fibers form significantly increases, with lag times $\left(t_{\text {lag }}\right)$ reduced by more than four-fold [23]. The $\mathrm{pH}$ dependence of the fiber growth rates bears a strong resemblance to the protonation state of the histidine residues $\left(\mathrm{pK}_{\mathrm{a}}\right.$ 6.7) and the $\mathrm{N}$-terminal amino group $\left(\mathrm{pK}_{\mathrm{a}} 7.9\right)$ within $A \beta$, consequently, the net charge of $A \beta$ is crucial to its amyloidogenicity.

As with $\mathrm{pH}$, the binding of metal ions will also change the net charge of $\mathrm{A} \beta \cdot \mathrm{Cu}^{2+}\left(\right.$ and $\mathrm{Zn}^{2+}$ ) ions bind to the three histidine residues within $\mathrm{A} \beta[10,22,46,53,54,56,57]$, at $\mathrm{pH} 7.4 \mathrm{~A} \beta$ 's histidine residues are predominately $(80 \%)$ deprotonated and neutrally charged, thus coordination of $\mathrm{Cu}^{2+}$ (or $\mathrm{Zn}^{2+}$ ) to $\mathrm{A} \beta$ 's histidines adds two positive charges. Adding positive charge to $\mathrm{A} \beta$ at $\mathrm{pH} 7.4$ makes the $\mathrm{A} \beta$ peptide complex more neutral in overall net charge, and 
therefore more prone to self-association, with the result that fiber growth times are almost halved. It seems the most probable cause of $\mathrm{Cu}^{2+}$ ion accelerated fiber formation kinetics is the reduction in the net charge of $\mathrm{A} \beta$ which promotes self-association. It is notable the metal coordination involving amide ligands (as is the case for PrP and $\alpha$ Syn, see Figure 3), will result in deprotonation. Thus the net change in charge upon $\mathrm{Cu}^{2+}$ binding may be small, or even cause a loss of positive charge.

\section{3) $C u-A \beta$ and Cell Toxicity}

There are a number of studies investigating the effect of $\mathrm{Cu}^{2+}$ on the cell-toxicity of $\mathrm{A} \beta[23$, $109,112,120-122]$. At first glance these studies seem to report conflicting observations. In some studies enhanced cytotoxicity is reported for $\mathrm{Cu}^{2+}$ plus $\mathrm{A} \beta$ [121], while others report that $\mathrm{Cu}^{2+}$ has a protective effect on $\mathrm{A} \beta$ toxicity $[109,112]$. When the nature of the $\mathrm{A} \beta$ preparation is considered (e.g. amorphous aggregates, monomers or fibers) the various studies become more consistent. When supra-stoichiometric levels of $\mathrm{Cu}^{2+}$ are used, amorphous aggregates are generated, which are not cytotoxic, but when sub-stoichiometric amounts of $\mathrm{Cu}^{2+}$ are used, $\mathrm{A} \beta$ fibers are generated and the presence of $\mathrm{Cu}^{2+}$ will significantly enhance the cytotoxicity. Sarell et al have shown both the protective effect of $\mathrm{Cu}^{2+}$ at supra-stoichiometric levels together with enhanced cytotoxicity for sub-stoichiometric levels [23], as shown in Figure 6. In vivo, A $\beta$ is present at lower levels than for the in vitro experiments and sub-stoichiometric levels of $\mathrm{Cu}^{2+}$ are the more physiologically relevant case, suggesting a role for $\mathrm{Cu}^{2+}$ ions in enhancing $\mathrm{A} \beta$ 's cytotoxicity.

The mechanism by which $\mathrm{A} \beta$ is toxic to cells (irrespective of the presence of $\mathrm{Cu}^{2+}$ ions) is hotly debated $[32,123]$. It is often suggested that $A \beta$ acts at the membrane surface to disrupt its integrity; thinning or forming pores in the plasma membrane to cause membrane leakage and loss of cellular $\mathrm{Ca}^{2+}$ homeostasis. One popular hypothesis is that the membrane integrity is compromised by lipid peroxidation from reactive oxygen species (ROS), which is a feature of the pathogenesis of $\mathrm{AD}$ and other protein misfolding diseases [124]. One key observation shows that hydrogen peroxide mediates $\mathrm{A} \beta$ toxicity and the anti-oxidant enzyme catalase protects cells from $\mathrm{A} \beta$ toxicity $[40,121,122]$. Fenton redox cycling of copper or iron ions are a likely source of extra-cellular $\mathrm{H}_{2} \mathrm{O}_{2}$ [125]. Indeed $\mathrm{Cu}^{2+}$ bound to $\mathrm{A} \beta$ will readily generate hydroxyl radicals and $\mathrm{H}_{2} \mathrm{O}_{2}$ in the presence of a physiological reductant such as ascorbate [28, 121, 126, 127]. Furthermore, metallothionein-3 (MT3) will competitively bind copper ions in a redox-inactive form, which will suppress A $\beta$ 's cytotoxicity [120]. An interesting recent study 
has highlighted the role of copper bound prion protein in mediating $\mathrm{A} \beta$ neuronal toxicity [42] and is discussed further in see section 10.3.

The precise reasons for the enhanced cytotoxicity of $\mathrm{A} \beta$ in the presence of $\mathrm{Cu}^{2+}$ ions are not clear. $\mathrm{A} \beta$ could bind $\mathrm{Cu}^{2+}$ promoting oligomer and fiber formation, which may result in an increase concentration of $\mathrm{Cu}^{2+}$ ions at the neuronal cell surface in a redox active form, where $\mathrm{Cu}^{2+}$ would generate toxic hydrogen peroxide and hydroxyl radicals. $\mathrm{A} \beta$ oligomers are found clustered at synaptic terminals [128] and cause memory loss due to synaptic failure [31]. The observation that the anti-oxidant protein catalase and the $\mathrm{Cu}^{2+}$ binding metallothionein-3 (MT3) are protective to cell-culture, strongly supports this hypothesis [40, 120-122]. Alternatively, the $\mathrm{Cu}^{2+}$ ions could alter the morphology of the fiber or increase the level oligomers relative to fibers, promoting an enhanced toxic effect to the cells. The heightened toxicity may be due to a combination of ROS generation and changes in the morphology of fiber/oligomer generated with sub-stoichiometric amounts of $\mathrm{Cu}^{2+}$ ions. Cytotoxicity studies by Sarell et al suggest that toxicity is not exclusively due to $\operatorname{ROS}$ as $\mathrm{A} \beta$ toxicity does not increase commensurately with increased loading of $\mathrm{Cu}^{2+}$ ions [23]. Thus the ability of $\mathrm{Cu}^{2+}$ to promote fiber growth (and by inference the interplay between monmer, oligomer and fiber) and the ability of $\mathrm{Cu}^{2+}$ to affect fiber morphology appears to be the significant factor in $\mathrm{Cu}^{2+} / \mathrm{ROS}$ promoted $\mathrm{A} \beta$ cell toxicity.

\section{4) $\mathrm{Zn}^{2+} A \beta$, fiber inhibition, oligomer promotion}

If $\mathrm{Cu}^{2+}$ ions accelerate fiber formation at sub-stoichiometric levels, what about other divalent metal ions? Interestingly, $\mathrm{Zn}^{2+}$ ions appear to completely inhibit fiber formation even at low $\mathrm{A} \beta$ (3 micro-molar) and zinc ion levels [23]. Indeed millisecond pulses to $\mathrm{Zn}^{2+}$ ions (mimicking pulses of $\mathrm{Zn}^{2+}$ that occur at the synapse) can stimulate $\mathrm{A} \beta$ aggregation and inhibit fiber formation [129]. A recent paper by Chen et al also showed little ThT fluorescence in the presence of $\mathrm{Zn}^{2+}$, even at sub-stoichiometric levels of $\mathrm{Zn}^{2+}$ [24]. Unlike $\mathrm{Cu}^{2+}$, TEM images of $\mathrm{Zn}^{2+}$ loaded $\mathrm{A} \beta$ showed no fibers were generated. This may be due to the very different complex (at micromolar concentration) between the two metal ions. $\mathrm{Cu}^{2+}$ ions form an intramolecular complex with $\mathrm{A} \beta[53,54,56,57]$, while at micromolar concentrations of $\mathrm{A} \beta$, it appears $\mathrm{Zn}^{2+}$ will form an inter-molecular complex; cross-linking between histidine residues on multiple $\mathrm{A} \beta$ molecules $[22,46,63,130]$. It is probable that a cross-linked $\mathrm{Zn}^{2+}-\mathrm{A} \beta$ species will inhibit amyloids forming by interfering with the regular cross-beta assembly. These in vitro experiments were performed at 3 micromolar concentrations of $\mathrm{A} \beta$. It may be that in vivo, where $\mathrm{A} \beta$ is much less concentrated ( 0.1 nanomolar), inter-molecular $\mathrm{Zn}^{2+}$ complexes may be 
less favored and thus the $\mathrm{Zn}^{2+}$ might, like $\mathrm{Cu}^{2+}$, form only intra-molecular complex with histidine side chains and so accelerate fiber formation in vivo with a similar mechanism to $\mathrm{Cu}^{2+}$ ions.

Interestingly, $\mathrm{A} \beta$ aggregates generated by the presence of $\mathrm{Zn}^{2+}$ showed a positive binding in a dot-blot antibody assay for $A \beta$ oligomers [24]. In contrast, the A11 antibody which recognized $\mathrm{A} \beta$ oligomers did not bind with metal free $\mathrm{A} \beta$ or $\mathrm{A} \beta$ loaded with $\mathrm{Cu}^{2+}$ or $\mathrm{Fe}^{3+}$ [24]. TEM images of the $\mathrm{Zn}^{2+}$ loaded $\mathrm{A} \beta$ showed ring-shape, pore-like oligomers in the pellet of $\mathrm{Zn}^{2+}$ promoted $\mathrm{A} \beta$ aggregates. The $\mathrm{Zn}^{2+}$ induced oligomers resemble previously characterized annular protofibrils [33]. It remains to be established if the $\mathrm{Zn}^{2+}$ promoted oligomers will affect cell membrane integrity.

\section{5) $\mathrm{Fe}^{3+}-\mathrm{A \beta}$ :}

Although $\mathrm{Fe}^{2+}$ binds specifically to $\mathrm{A} \beta[131]$ the affinity of $\mathrm{Fe}^{3+}$ for $\mathrm{A} \beta$ appears to be very weak [132, 133] and thus one might have predicted little evidence for a link between iron homeostasis and AD, however the opposite is the case. Significantly in both fly [134], [26] and mice [135] models of $\mathrm{AD}$, iron regulation has been shown to exacerbate the disease phenotype. For $\mathrm{A} \beta$ fibrils generated in the presence of $\mathrm{Fe}^{3+}$, the rate of formation is inhibited [26] particularly at above stoichiometric amounts of $\mathrm{Fe}^{3+}[24]$. A study by Crowther et al has suggested that $\mathrm{Fe}^{3+}$ influences the morphology of $\mathrm{A} \beta$ fibers with shorter more curved fibers generated, and it is suggested that it may be this which influences $A \beta$ toxicity in the fly [26].

\section{6) $C a^{2+} A \underline{\beta}$}

$\mathrm{Ca}^{2+}$ is found at very high concentrations extra-cellularly, relative to transition metal ions, typically at 2 millimolar in the extra-cellular space. Interestingly in vitro $\mathrm{Ca}^{2+}$ can accelerate $\mathrm{A} \beta$ fiber formation [136]. Ahmad et al have shown that at physiological levels of $\mathrm{Ca}^{2+}(2$ millimolar), the kinetics of $\mathrm{A} \beta(1-42)$ amyloid fiber formation is greatly accelerated, doubling the lag-time [137]. Surprisingly, no such effect was observed for $\mathrm{Ca}^{2+}$ addition to $\mathrm{A} \beta(1-40)$ solutions [137]. $\mathrm{Ca}^{2+}$ is a hard metal ion and coordinates via oxygen ligands. There are six Asp/Glu residues, largely in the N-terminal half of $\mathrm{A} \beta$, with which $\mathrm{Ca}^{2+}$ can coordinate. It is notable that $\mathrm{Ca}^{2+}$ (like $\mathrm{Cu}^{2+}$ ) binding will add positive charge to $\mathrm{A} \beta$ at $\mathrm{pH} 7.4$, making it more neutrally charged and, therefore, more prone to self-association. Whether $\mathrm{Ca}^{2+}$ homeostasis has an influence on the pathology of $\mathrm{AD}$ is not established. Although $\mathrm{Ca}^{2+}$ is an abundant bulk metal ion, it is not clear if $\mathrm{AD}$ pathology will be strongly influenced by fluctuations in $\mathrm{Ca}^{2+}$ 
levels outside the cell. However, the high extra cellular levels of $\mathrm{Ca}^{2+}$ may influence the critical concentration for fibril formation and could explain why sub-nanomolar levels of extracellular $\mathrm{A} \beta$ may be sufficient to cause fibers to form in vivo.

\section{7) $A l^{3+} A \beta$ :}

Fibril growth kinetics, using ThT, indicate little effect on the rate of fiber formation for $\mathrm{Ab}: \mathrm{Al}^{3+}$ ratios of $1: 1$ or 1:4. At higher levels of $\mathrm{Al}^{3+}$, fiber formation is strongly inhibited [24]. The influence of $\mathrm{Al}^{3+}$ on $\mathrm{AD}$ aetiology is reviewed in detail elsewhere in the special issue.

\section{7) Metal ions and amyloid formation in transmissible spongiform encotholthapies (TSE)}

Although the coordination geometry and affinity of $\mathrm{Cu}^{2+}$ binding to $\operatorname{PrP}^{\mathrm{C}}$ has been studied extensively $[16,50,51,85,138,139]$, there are surprisingly few studies of $\mathrm{Cu}^{2+}$ binding to prion protein fibers or studies on the influence of metal ions on the kinetics of fiber formation. It has been shown that $\mathrm{Cu}^{2+}$ promotes aggregation of PrP, lowers PrP solubility and promotes self-association [140-142]. In addition, $\mathrm{Cu}^{2+}$ ions can convert the $\mathrm{PrP}^{\mathrm{C}}$ into a protease-resistant species [140, 143-145], which is a feature of $\mathrm{PrP}^{\mathrm{Sc}}$. Furthermore, $\mathrm{Cu}^{2+}$ binding encodes features that correlate with various strains of prion disease [20]. There is a report using dynamic light scattering that indicates at millimolar levels, $\mathrm{Cu}^{2+}$ promotes oligomers of PrP, while the presence of amyloids were not well characterized [140]. Furthermore, $\mathrm{Cu}^{2+}$ has been shown to promote the formation of soluble oligomers at $\mathrm{pH} 5$, these $\mathrm{Cu}-\mathrm{PrP}$ oligomer will reduce cell viability in a SKNSH cell line [146].

A careful study by Baskakov et al showed that at 1 micromolar $\mathrm{Cu}^{2+}$ levels, 1:1 ratio with $\mathrm{PrP}^{\mathrm{C}}$, there appears to be little effect on prion protein fiber kinetics. At 10 mole equivalents, $\mathrm{Cu}^{2+}$ fiber formation was inhibited and at 100 micromolar $\mathrm{Cu}^{2+}(1$ micromolar $\operatorname{PrP})$, no fiber formation was observed. [147]. This behavior has some parallels with $\mathrm{Cu}^{2+}$ binding to $\mathrm{A} \beta$ as surpra-stoichiometric ratios of $\mathrm{Cu}^{2+}$ cause self-association of $\mathrm{A} \beta$ into amorphous aggregates and so inhibit fibrillization [23]. As with all in vitro studies there remains a question as to how well the in vitro, observations reflect the in vivo situation. $\mathrm{Cu}^{2+}$ induced self-association of $\operatorname{PrP}$ in the form of amorphous aggregates hints at the possibility that in vitro where $\operatorname{PrP}^{\mathrm{C}}$ is at lower concentrations anchored to the plasma membrane surface, fibrillization might occur rather than aggregation, as is the case for $\mathrm{A} \beta$ [23]. Interestingly, the same Baskakov et al study showed that once amyloid fibers are formed, the presence of $\mathrm{Cu}^{2+}$ can affect the morphology of the fibers. $\mathrm{Cu}^{2+}$ enhances PK-resistance of preformed fibrils and initiates aggregation of preformed PrP fibrils into larger plaque like clumps [147]. Baskakov et al also showed that $\mathrm{Zn}^{2+}$ at 1:1 
ratios has little effect on fibrillization, but at higher levels inhibited fiber formation, but to a lesser extent than $\mathrm{Cu}^{2+}$ ions. $\mathrm{Mn}^{2+}$ had little effect on fibrillization rates even at 100 mole equivalents [147].

\section{8) Metal ions and amyloid formation of $\alpha$ Syn in Parkinson's disease (PD)}

Metals have also been proposed as triggers for other misfolding and assembly diseases, including Parkinson's disease (PD). The acceleration of the kinetics of fiber formation of $\alpha \mathrm{Syn}$ was described over ten years ago [104, 148, 149]. However, these early studies used high levels of metal ions, higher than those normally found physiologically. Using 0.5-5 mM concentrations, a number of transition metal ions increased the rate at which $\alpha$ Syn formed amyloid fibers. Significantly, subsequent studies by Fernandez et al, using much lower concentrations of $\mathrm{Cu}^{2+}$ ions also accelerated fiber formation. [89] They showed that a 1:1 binding of $\mathrm{Cu}^{2+}$ with 100 micromolar of $\alpha$ Syn will significantly reduce the lag-time of fibrillization. A follow up study investigating the effect of other divalent transition metal ions; $\mathrm{Mn}^{2+}, \mathrm{Fe}^{3+}, \mathrm{Co}^{2+}$ and $\mathrm{Ni}^{2+}$ showed little or no effect on the kinetics of $\alpha \mathrm{Syn}$ fibril formation using 1:1 metal: $\alpha$ Syn ratios [99]. These metal ions have very low affinities for $\alpha$ Syn in the millimolar range, and as a consequence, at these more physiologically relevant levels (100 micromolar $\alpha$ Syn) there are few of these metal ions bound to $\alpha$ Syn. Furthermore, $\mathrm{Cu}^{2+}$ will exacerbate the cytotoxicity of $\alpha \mathrm{Syn}$ as assessed by additions of $\mathrm{Cu}-\alpha \mathrm{Syn}$ to cell culture [150].

\section{9) Metal ions and amyloid formation in other protein misfolding diseases}

Metals have also been proposed as triggers for other misfolding and assembly diseases such as dialysis-related amyloidosis [21]. Here $\mathrm{Cu}^{2+}$ binds to $\beta 2$-microglobulin $(\beta 2 \mathrm{~m})$ and causes a key cis-trans isomerization of a proline at position 32. Another protein perturbed by metal ions is the human islet amyloid peptide (hIAPP); a highly amyloidogenic peptide found in the islet cells of patients with type-II diabetes. hIAPP is toxic to $\beta$-cells and is linked to a loss of insulin secretion. Although highly amyloidogenic, hIAPP is safely stored in the secretory granules at high concentrations. Interestingly, unusually high millimolar levels of $\mathrm{Zn}^{2+}$ are found in pancreatic $\beta$-cells. It has been shown that these high levels of $\mathrm{Zn}^{2+}$ will inhibit hIAPP fiber formation. This raises the possibility that zinc has a protective role in hIAPP amyloid formation associated with type-II diabetes $[151,152] . \mathrm{Cu}^{2+}$ will also inhibit hIAPP amyloid formation [153]. Aberrant metal binding is also implicated in the misfolding and accumulation of $\mathrm{Cu}-\mathrm{Zn}$-superoxide dismutase (SOD) in amyotrophic lateral sclerosis (ALS) [154]. While 
Huntington's Disease, a poly-glutamate protein misfolding disease, has also been linked with copper promoted aggregation [155].

\section{0) Metal ion homeostasis at the synapse and metal ion affinities for $A \beta$ and $\operatorname{Pr} P$}

From the previous sections it clear there is now compelling data to show that metal ions influence, and can accelerate fiber formation and enhance cytotoxicity. However, a role for metal ions in protein misfolding diseases remains controversial, as it is often believed that the affinity of $A \beta$ and PrP for metal ions is not sufficiently high to be physiologically relevant. This section highlights some pertinent features of metal ions at the synapse and protein affinities.

\section{1) $\mathrm{Cu}^{2+}$ and $\mathrm{Zn}^{2+}$ at the synapse:}

$\mathrm{A} \beta$ and $\operatorname{PrP}$ are found concentrated at the synaptic cleft, as shown in Figure $7 . \operatorname{PrP}^{\mathrm{C}}$ is found bound to the extra-cellular membrane, while $\mathrm{A} \beta$ is released at the synapse $[128,156,157]$. The concentrations of metal ions at the synapse are therefore of particular interest as it is now established that $\mathrm{Zn}^{2+}$ and $\mathrm{Cu}^{2+}$ are released at the glutamatergic synapse in the cortex and hippocampus. There are now a number of excellent reviews describing what is known about $\mathrm{Zn}^{2+}$ and $\mathrm{Cu}^{2+}$ at the synapse $[8,158-160]$. This synapse is the site of long-term potentiation, which is responsible for memory formation and it is here that $\mathrm{A} \beta$ amyloid deposits are first observed in $\mathrm{AD}$ patients. $\mathrm{Zn}^{2+}$ ions are released, possibly with glutamate, during neurotransmission [161], fluxes of $\mathrm{Zn}^{2+}$ released into the extracellular space may be as free ionic form or as exchangeable $\mathrm{Zn}^{2+}$ at 10-30 micromolar levels [162]. It is believed $\mathrm{Zn}^{2+}$ will reach even higher levels during brief synaptic release events, perhaps 100-300 micromolar $[158,163,164]$. Similarly there is a release of exchangeable copper post-synaptically following activation of the NMDA receptor [165-167], Figure 7. It is believed $\mathrm{Cu}^{2+}$ reaches levels of 15 micromolar [168], some have reported even higher fluxes of $\mathrm{Cu}^{2+}$ from 20-250 micromolar, during neuronal depolarization $[17,169]$.

\section{2) $A \beta$ and $\operatorname{PrP}$ affinity for metal ions:}

A role for metal ions in protein misfolding is often disputed on the basis of insufficient metal protein affinity. Affinity measurements are a potentially difficult area and are often plagued with conflicting observations. An excellent review that highlights some of the common potential pitfalls in metal affinity measurements and calculations see [170]. For example, often the effect of competing buffers, multiple binding modes of competing ligands, the solubility of the metal ion and competing ligand, or its oxidation state as well as the $\mathrm{pH}$ dependence on the 
affinity are sometimes incorrectly understood or simply not considered. There have been numerous metal affinities reported for $\mathrm{A} \beta, \operatorname{PrP}^{\mathrm{C}}$ and $\alpha \mathrm{Syn}$ over the past decayed but now perhaps a consensus is emerging. Table 2 highlights some key measurements of conditional dissociation constants at $\mathrm{pH} 7.4$ for copper binding to $\mathrm{A} \beta, \operatorname{PrP}^{\mathrm{C}}$ and $\alpha \mathrm{Syn}$. Affinities shown in Table 2 are by no means a comprehensive list, it's purpose is to highlight some of the key recent studies. For a more complete review of this area and a discussion of conditional binding constant that take into account the competitive effects of buffers, see Faller et al [46].

The affinity of $\mathrm{Cu}^{2+}$ for $\mathrm{A} \beta$ has been calculated using 3 different competing ligands; very similar $\mathrm{K}_{\mathrm{d}} \mathrm{s}$ are observed for monomeric and fibrilar $\mathrm{A} \beta$ for all 3 competing ligands. Setting the conditional dissociation constant, $\mathrm{pH} 7.4$, at $54+/-5$ picomolar $\left(54 \times 10^{-12} \mathrm{M}\right)$ [53]. The use of three different competitors for $\mathrm{Cu}^{2+}$ that all indicate almost identical affinities for the $\mathrm{Cu}^{2+}-\mathrm{A} \beta$ complex indicates that a ternary complex, which might complicate the determination of $\mathrm{a} \mathrm{Cu}^{2+}$ affinity, does not from. Hatcher et al [171] and Tougo et al [172] have reported $\mathrm{Cu}^{2+}$ affinities a single order of magnitude weaker.

Extra-cellular monomeric $\mathrm{A} \beta$ levels are thought to be 0.1-1 nanomolar $[173,174]$, while $\mathrm{A} \beta$ levels are higher in plaques and at the synapse. Extra-cellular $\mathrm{Cu}^{2+}$ levels in the brain interstitial fluid are typically $100 \mathrm{nM}$. A picomolar affinity for $\mathrm{Cu}^{2+}$ allows $\mathrm{A} \beta$ to compete for these ions with other extracellular $\mathrm{Cu}^{2+}$ chelators, especially at the synapse during neuronal depolarization where fluxes of $\mathrm{Cu}^{2+}$ are reported to be 20-250 micromolar and $\mathrm{A} \beta$ is localized [169].

$\mathrm{Zn}^{2+}$ affinities for $\mathrm{A} \beta$ are relatively weak, with 1-20 micromolar dissociation constants reported $[46,175]$. However, it is known that exchangeable or free $\mathrm{Zn}^{2+}$ ions can reach levels as high as 30-300 micromolar at the glutamatergic synapse $[158,163,164]$. Thus $\mathrm{Zn}-\mathrm{A} \beta$ interactions may also be physiologically relevant.

$\operatorname{PrP}^{\mathrm{C}}$ has as many as six binding sites with 30-100 nanomolar affinities [85]. Others have reported Kds to within one or two orders of magnitude $[72,73,176] . \operatorname{PrP}^{\mathrm{C}}$ is situated at the plasma membrane of the synapse, with 6 potential $\mathrm{Cu}^{2+}$ binding sites on the flexible $\mathrm{N}$-terminal domain, it must, therefore, make it a good buffer for micro-molar fluxes of $\mathrm{Cu}^{2+}$ at the synapse. $\mathrm{Cu}^{2+}$ is bound to $\mathrm{PrP}^{\mathrm{C}}$ in vivo [17] and furthermore $\mathrm{Cu}^{2+}$ and $\mathrm{Zn}^{2+}$ will trigger endocytosis of 
$\operatorname{PrP}^{\mathrm{C}}$. Rapid turnover of PrP and increased oxidative stress associated with PrP knockouts suggest that PrP might have a protective anti-oxidant role [29, 177, 178].

To make a prediction as to the likely levels of metal binding to $\operatorname{PrP}$ and $\mathrm{A} \beta$ in-vivo we also need to consider the levels of other metallo-proteins at the synaptic cleft. Metallothionein3, (MT3) found within neurons may be to buffer synaptic fluxes of $\mathrm{Cu}^{2+}$ and $\mathrm{Zn}^{2+}$ as it is released in the cleft by near-by astrocytes [179]. MT3 binds $\mathrm{Cu}^{2+}$ in a redox inactive state and can protect against the toxic effects of $\mathrm{Cu}^{2+}$ and $\mathrm{Zn}^{2+}[120,158]$. Interestingly, MT3 levels are suppressed in $\mathrm{AD}$ patients [180], although this has been disputed [181]. In this situation, the buffering of these metal ions may become swamped and therefore available for binding $A \beta$ and PrP. Humans serum albumin highly concentrated in blood plasma, at 640 micromolar, and binds extra-cellular $\mathrm{Cu}^{2+}$ with a 1 picomolar affinity. However, the concentration of albumin is considerably lower in the CSF, ( 3 micromolar) and so may be swamped by spikes of $\mathrm{Cu}^{2+}$ at the synapse during neuronal depolarization, Figure 7.

\section{3) A $\beta$ toxicity mediated by copper bound $\operatorname{Pr}^{C}$ at the synapse}

Interestingly, both $\operatorname{PrP}^{\mathrm{C}}$ and $\mathrm{A} \beta$ are concentrated at the synapse and there is now strong evidence to link $\mathrm{A} \beta$ neurotoxicity with the presence of $\operatorname{PrP}^{\mathrm{C}}[182,183]$. $\mathrm{A} \beta$ toxicity in mice models of $A D$ requires the presence of $\operatorname{PrP}^{\mathrm{C}}$ [182]. Indeed $\operatorname{PrP}$ knockout mice can develop $\mathrm{A} \beta$ plaques but not neurotoxicity [184]. Interestingly $\operatorname{PrP}^{\mathrm{C}}$ selectively binds to $\mathrm{A} \beta$ oligomers $[185$, 186]. A molecular mechanism for the $\operatorname{PrP}^{\mathrm{C}}$ dependent $\mathrm{A} \beta$ toxicity has recently been proposed which indicates $A \beta$ disrupts copper homeostasis at the synapse which is required for normal $\operatorname{PrP}^{\mathrm{C}}$ dependent inhibition of excessive N-methyl-D-aspartate receptors (NMDAR) activity [42]. NMDA receptors mediate critical CNS functions, a physiological role for $\operatorname{PrP}^{\mathrm{C}}$, has been proposed that limits excessive NMDAR activity that might otherwise promote neuronal damage [187]. Significantly, $\operatorname{PrP}^{\mathrm{C}}$ only affects the NMDA receptor in a copper-loaded state [42]. There is evidence to suggest that the oligomeric form of $\mathrm{A} \beta$ released at the synapse, with a picomolar affinity for $\mathrm{Cu}^{2+}$, may disrupt $\mathrm{Cu}^{2+}$ binding to $\mathrm{PrP}^{\mathrm{C}}$ and so, in part at least, mediate neuronal and synaptic injury [42].

\section{1) In vivo evidence for a link between metal ions and protein misfolding diseases:}

From the previous section it is clear that the affinities of $\mathrm{A} \beta$ and $\operatorname{PrP}$ for $\mathrm{Cu}^{2+}$ and $\mathrm{Zn}^{2+}$ ions are sufficiently tight for them to be physiological relevant, particularly when fluxes of these ions are released at the synapse during neuronal depolarization. In this section evidence, from in 
vivo studies, in support of a role for metal ions in a number of protein misfolding diseases are highlighted.

\section{1) Alzheimer's disease $(A D)$ :}

Copper: In vivo studies using a Drosophila model of AD have shown that impaired copper homeostasis enhances the toxic effects of $\mathrm{A} \beta$ [188], while a rabbit model of Alzheimer's disease showed rabbits fed copper in a high cholesterol diet develop amyloid plaques and learning deficits [189]. In contrast, transgenic mice have shown a reduced AD pathology with increased intra-cellular copper levels [190-192]. Interestingly $\mathrm{Cu}^{+}$will also bind to $\mathrm{A} \beta$ and may therefore influence fiber formation [193]. Understanding the interplay between intra and extra cellular copper and its effect on $\mathrm{A} \beta$ will be essential for a more complete picture of copper related $\mathrm{AD}$ pathology [194]. It appears that $\mathrm{AD}$ may be characterized by an increase in labile extra-cellular pool of $\mathrm{Cu}^{2+}$ ions [195].

Zinc: $\mathrm{Zn}^{2+}$ is concentrated in synaptic vesicles with the assistance of a specific zinc transporter, Zn-T3. Significantly, a mouse model of AD with Zn-T3 knocked out do not develop amyloid plaques in the brain [196]. Furthermore, MT3 is released by astrocytes at the synaptic cleft and have a role in buffering $\mathrm{Cu}^{2+}$ and $\mathrm{Zn}^{2+}$. Interestingly, MT3 (GIF) levels are reduced by an order of magnitude in AD patients [180] although this is contested [181].

Iron: Significantly, in both fly [26, 134] and mice [135] models of $\mathrm{AD}$, iron regulation has been shown to exacerbate the disease phenotype; reducing fly longevity and increasing rough eye. In particular, ferritin, the iron storage protein, will influence the disease phenotype [26, $134]$.

\section{2) TSE:}

The relationship between metal ions and prion disease have been reviewed [50, 51, 138, 139]. A feature of prion disease are metal imbalances [19]. Copper shows an increase in toxicity for PrP knockout mice and exacerbates disease in a mouse model of familial CJD [197]. Increased copper in the diet of mice raises $\operatorname{PrP}^{\mathrm{C}}$ levels; although counter intuitively survival times after scrapie infection are reduce with mice fed a low copper diet [18]. Furthermore, when isolated from diseased brain, $\mathrm{PrP}^{\mathrm{Sc}}$ has been found to be occupied with $\mathrm{Cu}^{2+}$ ions [20]. Different strains of prion disease may be generated depending on the presence, or absence, of $\mathrm{Cu}^{2+}$ ions [20]. PrP knockouts show altered metal ion homeostasis in the mice brain [198]. Protease resistance in $\mathrm{PrP}$ is induced upon $\mathrm{Cu}^{2+}$ binding $[144,145]$. Younan et al have recently shown $\mathrm{Cu}^{2+}$ ions 
can destabilize the fold of $\operatorname{PrP}^{\mathrm{C}}$. The free energy of folding is lowered by $2 \mathrm{~kJ} / \mathrm{mol}$ and therefore may make the transition to misfolded $\mathrm{PrP}^{\mathrm{Sc}}$ more thermodynamically favorable [25]. A form of familial prion disease is linked to an increased ability to bind $\mathrm{Cu}^{2+}$ ions with additional octarepeats present, while $\mathrm{Cu}^{2+}$ binding to the amyloidgenic fragment of $\operatorname{PrP}$ is linked to increased neurotoxicity [199-201]. In addition, oxidative modifications of PrP, generated by copper catalyzed Fenton reaction has been linked to prion disease [29, 30, 202]. Significantly, copper ion chelation therapy will delay onset of scrapie in mice [203].

\section{3) Parkinson's Disease (PD) :}

An increased risk of developing PD has been linked to industrial exposure to heavy metal ions [204]. Elevated levels of $\mathrm{Cu}^{2+}$ have been reported in the cerebrospinal fluid of PD patients [14], in addition iron deposits have been found in the lewy bodies [15]. Further details are discussed elsewhere in this special issue.

\section{2) Is there a shared metal associated mechanism of amyloidoses?}

It is believed that all proteins under the right conditions will form amyloid structures with a shared generic cross-beta structural motif [1]. Perhaps the mechanism by which metal ions accelerate fiber formation is also shared. Sarell et al has proposed that metal accelerated fiber formation for $\mathrm{A} \beta$ might be driven by electrostatics [23]. At $\mathrm{pH} 7.4$ metal ion coordination via imidazole side chains will cause the net charge of the protein to be more positive. However this is not always the case, if coordination is dominated by amides, as in the case of for some of the modes of coordination of $\mathrm{Cu}^{2+}$ to the prion protein (Figure 3) then $\mathrm{Cu}^{2+}$ binding will actually reduce the net charge, due to the loss of up to three protons upon forming the complex. Thus the change in net charge of the protein upon metal coordination is dependent on the type complex formed.

Theoretical pI's for a number of amyloidogenic proteins are given in Table 3. A $\beta$ and $\alpha$ Syn, have acidic pI's, 5.3 and 4.6 respectively. Using our understanding of the coordination geometry it appears $\mathrm{Cu}^{2+}$ at $\mathrm{pH} 7.4$ will make $\mathrm{A} \beta$ more neutrally charged. However the first equivalent of $\mathrm{Cu}^{2+}$ binding at the $\mathrm{N}$-terminus of $\alpha$-Syn will have little effect on the overall charge due to the displacement of two protons, one from the amino group and one from an amide (Figure 3 ). The prion protein possesses a basic pI, 9.8 so a neutral $\mathrm{pH}$ PrP is already positively charged, however $\mathrm{Cu}^{2+}$ binding dominated by amide proton displacement will make PrP more neutrally charged binding centred at His ${ }^{111}$ or His ${ }^{96}$ of PrP. Unlike A $\beta$ and $\alpha$ Syn, $\mathrm{Cu}^{2+}$ binding to PrP have been reported to inhibit fiber formation [147]. 
The acceleration of fiber formation upon metal bind may be a combination of a number of effects, and a change in net charge is just one of these. It does not appear that all metal associated amyloidosis are related to a change in net charge and increased self-association. $\mathrm{Cu}^{2+}$ binding to $\beta 2 \mathrm{~m}$ appears to be closely related to a structural rearrangement induced by $\mathrm{Cu}^{2+}$ binding rather than a change in net charge [21]. While in SOD, it is the destabilization of the native fold of the protein due to a point mutation and a loss of a zinc ligand that destabilizes the native protein fold [154].

\section{3) Concluding remarks}

Metal ions are capable of affecting amorphous aggregation, oligomerization and fibrillization of a number of amyloidogenic proteins associated with protein misfolding [21, 89, 147, 151]. Furthermore, metal ion homeostasis, particularly at the synapse, where $\mathrm{Zn}^{2+}$ and $\mathrm{Cu}^{2+}$ are released as a labile pool is now being recognized as a potential risk-factor in these multifactorial diseases. In particular, for Alzheimer's disease (AD), it is now established that $A \beta$ has a tight, physiologically relevant, picomolar affinity for $\mathrm{Cu}^{2+}[53]$. Furthermore, $\mathrm{Cu}^{2+}$ binding significantly accelerates the rate of fiber formation and enhances cytotoxicity in cell culture [23]. These observations are supported by in vivo studies in animal models of AD that implicate $\mathrm{Cu}^{2+}$ impaired homeostasis in promotion of the disease [188, 189]. A recent study suggests the toxicity of $A \beta$ is mediated by both copper ions and the prion protein [42]. This is a particularly exciting new development linking copper homeostasis at the synapse with two amyloidogenic proteins, and is set to generate a major paradigm shift in our understanding of Alzheimer's disease.

\section{Acknowledgments:}

This work was supported by the Welcome Trust, project grant 093241/Z/10/Z. With thanks to Nadine Younan, Helen Stanyon, Christopher Matheou and Grainne Viles for helpful suggestions and encouragement. 


\section{Figure Captions}

Figure 1: Potential mechanisms by which metal ions can perturb protein fiber formation:

i) Metal induced conformational change. ii) Metal induced cross-linking. iii) Metal induced neutral net charge iv) Metal induced change in fiber morphology. v) Metal induced change in protein stability.

Figure 2: Fibers versus amorphous aggregates. Fibers are in equilibrium with, oligomers, monomers and amorphous aggregates and there relative proportions are interdependent.

Figure 3: $\mathbf{C u}^{2+}$ coordination to $\mathbf{A} \boldsymbol{\beta}, \operatorname{PrP}$ and $\boldsymbol{\alpha} \mathbf{S y n}$. These are models adapted from [53, 55] for $\mathrm{A} \beta$ [16] for the prion protein modes of coordination (mouse sequence numbering) and [94] for $\alpha$-synuclein.

Figure 4: Fiber growth kinetics. Nucleation-polymerization reaction causes a sigmoidal growth curve with a lag-phase and elongation. Fiber formation is initially very slow until nucleating seeds are generated; this initiate's rapid fiber generation until equilibrium with low amounts of protein monomer is reached. Agitation will cause fragmentation and additional secondary nucleation and a reduced lag-phase.

Figure 5: $\mathbf{C u}^{2+}$ accelerates fiber growth. (a) Average of 9 growth curves recorded on two separate occasions, apo in red, 1 mole equivalent $\mathrm{Cu}^{2+}$ in blue. The fluorescence ThT signal is normalized at maximal intensity. A $\beta(1-40) 5$ micromolar, HEPES buffer $50 \mathrm{mM}, 160 \mathrm{mM}$ $\mathrm{NaCl}$ at $30{ }^{\circ} \mathrm{C}$. (b) Time to reach half-maximal fluorescence $\left(\mathrm{t}_{50}\right)$ in two experiments with 0 (red), 1 (mid-blue) or 0.5 (dark blue) mole equivalents of $\mathrm{Cu}^{2+}$ ions. The presence of $\mathrm{Cu}^{2+}$ typically halves the time taken to form fibers. Error bars are for standard error (s.e.m.) from nine traces. $\mathrm{P}=0.001$ indicated by $* * *$. Adapted from [23].

Figure 6: Cell viability, $\mathbf{C} \mathbf{u}^{2+}-\mathbf{A} \boldsymbol{\beta}$ is more cytotoxic than $\mathbf{A} \boldsymbol{\beta} . \mathrm{A} \beta(1-42)$ as preformed fibrils, 3 micromolar, with and without the presence of 1.5 micromolar $\mathrm{Cu}^{2+}$ were added to $\mathrm{PC} 12$ cells. $\mathrm{Cu}^{2+}$ was added to the cells alone to test $\mathrm{Cu}^{2+}$ toxicity. Blank is buffer only. All preparations were incubated with the cells for $24 \mathrm{hrs}$ then $10 \%$ (v/v) Alamar Blue was added. The data shown here is after total incubation for $70 \mathrm{hrs}$. Error bars are standard error (s.e.m), $\mathrm{n}=3$. $\mathrm{P}=$ 0.001 indicated by $* * *$. Adapted from [23]. 
Figure 7: $\mathrm{Zn}^{2+}$ and $\mathrm{Cu}^{2+}$ at the synapse. Exchangeable $\mathrm{Zn}^{2+}$ is released with glutamate from vesicles at gutamergic synapse after neuronal excitation, 30-100 micromolar spikes of $\mathrm{Zn}^{2+}$ may be reached. $\mathrm{Cu}^{2+}$ is released postsynaptically after NMDA receptor activation, 15 micromolar or more fluxes of $\mathrm{Cu}^{2+}$ are reported. $\mathrm{A} \beta$ is cleaved from APP in to the lumin of vesicles as it travels down the axon, $A \beta$ is then released at the presynapse. PrP is anchored to the plasma membrane concentrated at the presynapse. ZnT-3 and the menkes protein, ATP7a, are key protein responsible for trafficking $\mathrm{Zn}^{2+}$ and $\mathrm{Cu}^{+}$respectively into vesicles. Metallothionein3 (MT3), released from astrocytes may serve as a buffer for the fluxes of $\mathrm{Zn}^{2+}$ and $\mathrm{Cu}^{2+}$ but may be depleted in Alzheimer's disease. 
Table 1: The effect of $\mathrm{Cu}^{2+}$ on $\mathrm{A} \beta$ fiber formation.

\begin{tabular}{|c|c|c|c|c|c|}
\hline $\begin{array}{l}\text { Stoichiometry } \\
{\left[\mathrm{Cu}^{2+}\right] /[\mathrm{A} \beta]}\end{array}$ & Peptide & $\begin{array}{l}\text { Concentration } \\
\text { (micromolar) }\end{array}$ & Technique & Observation & Ref \\
\hline 0.2 & $\mathrm{~A} \beta(1-40)$ & 5 & ThT & Accelerate fiber kinetics & {$[23]$} \\
\hline 0.5 & $\mathrm{~A} \beta(1-40)$ & 5 & ThT & Accelerate fiber kinetics & {$[23]$} \\
\hline 1 & $\mathrm{~A} \beta(1-40)$ & 5 & ThT & Accelerate fiber kinetics & [23] \\
\hline 0.5 & $\mathrm{~A} \beta(1-42)$ & 3 & ThT & Promotes fibers & [23] \\
\hline 2 & $\mathrm{~A} \beta(1-40)$ & 5 & ThT & No fibers & [23] \\
\hline 0.5 & $A \beta(1-40)$ & 50 & ThT & No fibers & {$[23]$} \\
\hline 2 & $\mathrm{~A} \beta(1-40)$ & 10 & ThT & No fibers & {$[109]$} \\
\hline 2 & $\mathrm{~A} \beta(1-42)$ & 10 & ThT & Reduced fibers & {$[109]$} \\
\hline 0.5 & $\mathrm{~A} \beta(1-42)$ & 5 & ThT & Reduced fibers & {$[112]$} \\
\hline 1.0 & $\mathrm{~A} \beta(1-42)$ & 5 & ThT & No fibers & {$[112]$} \\
\hline 1 & $\mathrm{~A} \beta(1-40)$ & 25 & ThT & Reduced fibers & [24] \\
\hline 0.2 & $\mathrm{~A} \beta(1-40)$ & 25 & TEM & Fibers observed & {$[24]$} \\
\hline 0.4 & $A \beta(1-40)$ & 50 & ThT & No fibers & {$[110]$} \\
\hline 0.2 & $\mathrm{~A} \beta(1-40)$ & 50 & ThT & Reduced fibers & {$[110]$} \\
\hline 1 & $\mathrm{~A} \beta(1-42)$ & 40 & ThT & Reduced fibers & {$[115]$} \\
\hline$<1$ & $A \beta(1-42)$ & -- & TEM & Fibers observed & [27] \\
\hline$>1$ & $\mathrm{~A} \beta(1-42)$ & -- & TEM & No fibers & [27] \\
\hline 1 & $\mathrm{~A} \beta(1-40)$ & -- & TEM & Fibers observed & {$[116]$} \\
\hline 2 & $\mathrm{~A} \beta(1-40)$ & -- & TEM & No fibers & {$[116]$} \\
\hline 0.5 & $\mathrm{~A} \beta(1-42)$ & -- & AFM & No fibers & {$[113]$} \\
\hline 0.7 & $\mathrm{~A} \beta(1-40)$ & 2.5 & Centrifugation & Increased precipitation & {$[107]$} \\
\hline 1 & $\mathrm{~A} \beta(1-40)$ & 20 & Absorption & Increase turbidity & {$[108]$} \\
\hline
\end{tabular}

The data is largely consistent with supra-stoichiometric amounts of $\mathrm{Cu}^{2+}$ or high concentration of $\mathrm{A} \beta$ generating amorphous aggregates. While at physiologically relevant lower concentrations and substoichiometric $\mathrm{Cu}^{2+}$ amyloid fibers are observer and their rate of formation is accelerated. 
Table 2: Copper $^{2+}$ affinities for synaptic amyloidogenic proteins.

\section{Protein}

Amyloid beta peptide $(\mathrm{A} \beta)$

Prion protein $\left(\operatorname{PrP}^{\mathrm{C}}\right) * *$

Alpha-synuclein ( $\alpha$ Syn)
Conditional $\mathrm{K}_{\mathrm{d}}$, pH 7.4

54 picomolar

400 picomolar

35 nanomolar (*625 picomolar)

30 nanomolar

3 nanomolar

0.1 nanomolar

0.4 nanomolar

0.2 nanomolar

0.1 nanomolar
Reference

[73]

[97]

[98]

[94]

Data presented are for conditional dissociation constant at $\mathrm{pH}$ 7.4. *Correction made for the buffer used. $* * \operatorname{PrP}^{\mathrm{C}}$ binds up to six $\mathrm{Cu}^{2+}$ ions, a weaker affinity of 100 nanomolar is reported for $\mathrm{Cu}^{2+}$ binding to single octarepeats. 
Table 3: pI's for amyloidogenic proteins and the effect of $\mathrm{Cu}^{2+}$ on fiber growth rates.

Protein

pI

Effect of $\mathrm{Cu}^{2+}$ on

Reference

Fiber growth kinetics

Amyloid-beta peptide $(\mathrm{A} \beta)$

5.3

Accelerate

Alpha-synuclein ( $\alpha$ Syn)

4.4

Accelerate

$\beta 2$-microglobulin ( $\beta 2 \mathrm{~m})$

6.5

Accelerate

Human Prion protein (PrP)

9.8

Inhibit

islet amyloid poly peptide (IAPP)

8.9

Inhibit

For protein with acid pI's amyloid fiber formation is accelerated while for basic proteins it is inhibited. 


\section{References}

1. $\quad$ C. M. Dobson. Nature 426 (2003) 884.

2. J. Hardy, and D. J. Selkoe. Science 297 (2002) 353.

3. M. H. Polymeropoulos, C. Lavedan, E. Leroy, S. E. Ide, A. Dehejia, A. Dutra, B. Pike, H. Root, J. Rubenstein, R. Boyer, E. S. Stenroos, S. Chandrasekharappa, A. Athanassiadou, T. Papapetropoulos, W. G. Johnson, A. M. Lazzarini, R. C. Duvoisin, G. Di Iorio, L. I. Golbe, and R. L. Nussbaum. Science 276 (1997) 2045.

4. $\quad$ S. B. Prusiner. Proc Natl Acad Sci U S A. 95 (1998) 13363.

5. D. J. Selkoe. J Biol Chem 271 (1996) 18295.

6. A. I. Bush. Curr Opin Chem Biol 4 (2000) 184.

7. A. I. Bush. Trends Neurosci 26 (2003) 207.

8. K. J. Barnham, and A. I. Bush. Curr Opin Chem Biol 12 (2008) 222.

9. P. Davies, S. N. Fontaine, D. Moualla, X. Y. Wang, J. A. Wright, and D. R. Brown. Biochem Soc T 36 (2008) 1299.

10. J. Dong, C. S. Atwood, V. E. Anderson, S. L. Siedlak, M. A. Smith, G. Perry, and P. R. Carey. Biochemistry 42 (2003) 2768.

11. M. A. Lovell, J. D. Robertson, W. J. Teesdale, J. L. Campbell, and W. R. Markesbery. J Neurol Sci 158 (1998) 47.

12. L. M. Miller, Q. Wang, T. P. Telivala, R. J. Smith, A. Lanzirotti, and J. Miklossy. J Struct Biol 155 (2006) 30.

13. M. Stoltenberg, M. Bruhn, C. Sondergaard, P. Doering, M. J. West, A. Larsen, J. C. Troncoso, and G. Danscher. Histochem Cell Biol 123 (2005) 605.

14. H. S. Pall, A. C. Williams, D. R. Blake, J. Lunec, J. M. Gutteridge, M. Hall, and A. Taylor. Lancet 2 (1987) 238.

15. R. J. Castellani, S. L. Siedlak, G. Perry, and M. A. Smith. Acta Neuropathol 100 (2000) 111.

16. M. Klewpatinond, P. Davies, S. Bowen, D. R. Brown, and J. H. Viles. J Biol Chem 283 (2008) 1870.

17. D. R. Brown, K. Qin, J. W. Herms, A. Madlung, J. Manson, R. Strome, P. E. Fraser, T. Kruck, A. von Bohlen, W. Schulz-Schaeffer, A. Giese, D. Westaway, and H. Kretzschmar. Nature 390 (1997) 684.

18. G. Mitteregger, S. Korte, M. Shakarami, J. Herms, and H. A. Kretzschmar. Brain Res 1292 (2009) 155.

19. A. M. Thackray, R. Knight, S. J. Haswell, R. Bujdoso, and D. R. Brown. Biochem J 362 (2002) 253.

20. J. D. Wadsworth, A. F. Hill, S. Joiner, G. S. Jackson, A. R. Clarke, and J. Collinge. Nat Cell Biol 1 (1999) 55.

21. M. F. Calabrese, C. M. Eakin, J. M. Wang, and A. D. Miranker. Nat Struct Mol Biol 15 (2008) 965.

22. C. D. Syme, and J. H. Viles. Biochim Biophys Acta 1764 (2006) 246.

23. C. J. Sarell, S. R. Wilkinson, and J. H. Viles. J Biol Chem 285 (2010) 41533.

24. W. T. Chen, Y. H. Liao, H. M. Yu, I. H. Cheng, and Y. R. Chen. J Biol Chem 286 (2011) 9646.

25. N. D. Younan, M. Klewpatinond, P. Davies, A. V. Ruban, D. R. Brown, and J. H. Viles. J Mol Biol 410 (2011) 369.

26. B. Liu, A. Moloney, S. Meehan, K. Morris, S. E. Thomas, L. C. Serpell, R. Hider, S. J. Marciniak, D. A. Lomas, and D. C. Crowther. J Biol Chem 286 (2011) 4248.

27. D. P. Smith, G. D. Ciccotosto, D. J. Tew, M. T. Fodero-Tavoletti, T. Johanssen, C. L. Masters, K. J. Barnham, and R. Cappai. Biochemistry 46 (2007) 2881. 
28. R. C. Nadal, S. E. Rigby, and J. H. Viles. Biochemistry 47 (2008) 11653.

29. R. C. Nadal, S. R. Abdelraheim, M. W. Brazier, S. E. Rigby, D. R. Brown, and J. H. Viles. Free Radic Biol Med 42 (2007) 79.

30. T. Canello, R. Engelstein, O. Moshel, K. Xanthopoulos, M. E. Juanes, J. Langeveld, T. Sklaviadis, M. Gasset, and R. Gabizon. Biochemistry 47 (2008) 8866.

31. D. M. Walsh, I. Klyubin, J. V. Fadeeva, W. K. Cullen, R. Anwyl, M. S. Wolfe, M. J. Rowan, and D. J. Selkoe. Nature 416 (2002) 535.

32. B. A. Yankner, and T. Lu. J Biol Chem 284 (2009) 4755.

33. C. G. Glabe. J Biol Chem 283 (2008) 29639.

34. M. Meyer-Luehmann, T. L. Spires-Jones, C. Prada, M. Garcia-Alloza, A. de Calignon, A. Rozkalne, J. Koenigsknecht-Talboo, D. M. Holtzman, B. J. Bacskai, and B. T. Hyman. Nature 451 (2008) 720.

35. B. Urbanc, L. Cruz, R. Le, J. Sanders, K. H. Ashe, K. Duff, H. E. Stanley, M. C. Irizarry, and B. T. Hyman. Proc Natl Acad Sci U S A 99 (2002) 13990.

36. H. A. Lashuel, D. Hartley, B. M. Petre, T. Walz, and P. T. Lansbury. Nature 418 (2002) 291.

37. W. F. Xue, A. L. Hellewell, W. S. Gosal, S. W. Homans, E. W. Hewitt, and S. E. Radford. J Biol Chem 284 (2009) 34272.

38. K. Murakami, K. Irie, A. Morimoto, H. Ohigashi, M. Shindo, M. Nagao, T. Shimizu, and T. Shirasawa. J Biol Chem 278 (2003) 46179.

39. K. A. Conway, J. D. Harper, and P. T. Lansbury. Nat Med 4 (1998) 1318.

40. C. Behl, J. B. Davis, R. Lesley, and D. Schubert. Cell 77 (1994) 817.

41. I. V. Murray, M. E. Sindoni, and P. H. Axelsen. Biochemistry 44 (2005) 12606.

42. H. You, S. Tsutsui, S. Hameed, T. J. Kannanayakal, L. Chen, P. Xia, J. D. Engbers, S. A. Lipton, P. K. Stys, and G. W. Zamponi. Proc Natl Acad Sci U S A 109 (2012) 1737.

43. R. Tycko. Curr Opin Struct Biol 14 (2004) 96.

44. T. Eichner, and S. E. Radford. Mol Cell 43 (2011) 8.

45. O. S. Makin, and L. C. Serpell. FEBS J 272 (2005) 5950.

46. P. Faller, and C. Hureau. Dalton Trans (2009) 1080.

47. P. Faller. Chembiochem 10 (2009) 2837.

48. V. Tougu, A. Tiiman, and P. Palumaa. Metallomics 3 (2011) 250.

49. G. L. Millhauser. Acc Chem Res 37 (2004) 79.

50. J. H. Viles, M. Klewpatinond, and R. C. Nadal. Biochem Soc Trans 36 (2008) 1288.

51. H. Kozlowski, M. Luczkowski, and M. Remelli. Dalton Trans 39 (2010) 6371.

52. J. A. Wright, and D. R. Brown. J Neurosci Res 86 (2008) 496.

53. C. J. Sarell, C. D. Syme, S. E. Rigby, and J. H. Viles. Biochemistry 48 (2009) 4388.

54. J. W. Karr, and V. A. Szalai. Biochemistry 47 (2008) 5006.

55. S. Parthasarathy, F. Long, Y. Miller, Y. Xiao, D. McElheny, K. Thurber, B. Ma, R. Nussinov, and Y. Ishii. J Am Chem Soc 133 (2011) 3390.

56. C. D. Syme, R. C. Nadal, S. E. Rigby, and J. H. Viles. J Biol Chem 279 (2004) 18169.

57. S. C. Drew, C. J. Noble, C. L. Masters, G. R. Hanson, and K. J. Barnham. J Am Chem Soc 131 (2009) 1195.

58. $\quad$ B. K. Shin, and S. Saxena. Biochemistry 47 (2008) 9117.

59. C. A. Damante, K. Osz, Z. Nagy, G. Pappalardo, G. Grasso, G. Impellizzeri, E. Rizzarelli, and I. Sovago. Inorg Chem (2008).

60. L. Hou, and M. G. Zagorski. J Am Chem Soc 128 (2006) 9260.

61. V. A. Streltsov, J. T. SJ, V. C. Epa, K. J. Barnham, C. L. Masters, and J. N. Varghese. Biophys J (2008).

62. O. N. Antzutkin. Magn Reson Chem 42 (2004) 231.

63. V. Minicozzi, F. Stellato, M. Comai, M. D. Serra, C. Potrich, W. Meyer-Klaucke, and S. Morante. J Biol Chem 283 (2008) 10784. 
64. P. Dorlet, S. Gambarelli, P. Faller, and C. Hureau. Angew Chem Int Ed Engl 48 (2009) 9273.

65. B. K. Shin, and S. Saxena. J Phys Chem A 115 (2011) 9590.

66. X. Lu, P. L. Wintrode, and W. K. Surewicz. Proc Natl Acad Sci U S A 104 (2007) 1510.

67. N. J. Cobb, F. D. Sonnichsen, H. McHaourab, and W. K. Surewicz. Proc Natl Acad Sci U S A 104 (2007) 18946.

68. J. H. Viles, F. E. Cohen, S. B. Prusiner, D. B. Goodin, P. E. Wright, and J. H. Dyson. Proc Natl Acad Sci U S A 96 (1999) 2042.

69. A. P. Garnett, and J. H. Viles. J Biol Chem 278 (2003) 6795.

70. C. S. Burns, E. Aronoff-Spencer, C. M. Dunham, P. Lario, N. I. Avdievich, W. E. Antholine, M. M. Olmstead, A. Vrielink, G. J. Gerfen, J. Peisach, W. G. Scott, and G. L. Millhauser. Biochemistry 41 (2002) 3991.

71. D. Valensin, M. Luczkowski, F. M. Mancini, A. Legowska, E. Gaggelli, G. Valensin, K. Rolka, and H. Kozlowski. Dalton Trans (2004) 1284.

72. M. A. Wells, C. Jelinska, L. L. Hosszu, C. J. Craven, A. R. Clarke, J. Collinge, J. P. Waltho, and G. S. Jackson. Biochem J 400 (2006) 501.

73. E. D. Walter, M. Chattopadhyay, and G. L. Millhauser. Biochemistry 45 (2006) 13083.

74. M. Chattopadhyay, E. D. Walter, D. J. Newell, P. J. Jackson, E. Aronoff-Spencer, J. Peisach, G. J. Gerfen, B. Bennett, W. E. Antholine, and G. L. Millhauser. J Am Chem Soc 127 (2005) 12647.

75. C. E. Jones, S. R. Abdelraheim, D. R. Brown, and J. H. Viles. J Biol Chem 279 (2004) 32018.

76. G. S. Jackson, I. Murray, L. L. P. Hosszu, N. Gibbs, J. P. Waltho, A. R. Clarke, and J. Collinge. Proceedings of the National Academy of Sciences USA. 98 (2001) 8531.

77. S. S. Hasnain, L. M. Murphy, R. W. Strange, J. G. Grossmann, A. R. Clarke, G. S. Jackson, and J. Collinge. Journal of Molecular Biology. 311 (2001) 467.

78. C. S. Burns, E. Aronoff-Spencer, G. Legname, S. B. Prusiner, W. E. Antholine, G. J. Gerfen, J. Peisach, and G. L. Millhauser. Biochemistry 44 (2003) 6794.

79. C. E. Jones, M. Klewpatinond, S. R. Abdelraheim, D. R. Brown, and J. H. Viles. J Mol Biol 346 (2005) 1393.

80. M. Klewpatinond, and J. H. Viles. Biochem J 404 (2007) 393.

81. E. Gralka, D. Valensin, E. Porciatti, C. Gajda, E. Gaggelli, G. Valensin, W. Kamysz, R. Nadolny, R. Guerrini, D. Bacco, M. Remelli, and H. Kozlowski. Dalton Trans (2008) 5207.

82. K. Osz, Z. Nagy, G. Pappalardo, G. Di Natale, D. Sanna, G. Micera, E. Rizzarelli, and I. Sovago. Chemistry 13 (2007) 7129.

83. F. Berti, E. Gaggelli, R. Guerrini, A. Janicka, H. Kozlowski, A. Legowska, H. Miecznikowska, C. Migliorini, R. Pogni, M. Remelli, K. Rolka, D. Valensin, and G. Valensin. Chemistry 13 (2007) 1991.

84. G. Di Natale, K. Osz, Z. Nagy, D. Sanna, G. Micera, G. Pappalardo, I. Sovago, and E. Rizzarelli. Inorg Chem 48 (2009) 4239.

85. R. C. Nadal, P. Davies, D. R. Brown, and J. H. Viles. Biochemistry 48 (2009) 8929.

86. A. Binolfi, A. A. Valiente-Gabioud, R. Duran, M. Zweckstetter, C. Griesinger, and C. O. Fernandez. J Am Chem Soc (2010).

87. R. Borghi, R. Marchese, A. Negro, L. Marinelli, G. Forloni, D. Zaccheo, G. Abbruzzese, and M. Tabaton. Neuroscience Letters 287 (2000) 65.

88. $\quad$ S. J. Lee. J Mol Neurosci 34 (2008) 17.

89. R. M. Rasia, C. W. Bertoncini, D. Marsh, W. Hoyer, D. Cherny, M. Zweckstetter, C. Griesinger, T. M. Jovin, and C. O. Fernandez. Proc Natl Acad Sci U S A 102 (2005) 4294. 
90. Y. H. Sung, C. Rospigliosi, and D. Eliezer. Biochim Biophys Acta 1764 (2006) 5.

91. P. Davies, X. Wang, C. J. Sarell, A. Drewett, F. Marken, J. H. Viles, and D. R. Brown. Biochemistry (2010).

92. A. Binolfi, G. R. Lamberto, R. Duran, L. Quintanar, C. W. Bertoncini, J. M. Souza, C. Cervenansky, M. Zweckstetter, C. Griesinger, and C. O. Fernandez. Journal of the American Chemical Society 130 (2008) 11801.

93. S. C. Drew, S. L. Leong, C. L. Pham, D. J. Tew, C. L. Masters, L. A. Miles, R. Cappai, and K. J. Barnham. J Am Chem Soc 130 (2008) 7766.

94. C. G. Dudzik, E. D. Walter, and G. L. Millhauser. Biochemistry 50 (2011) 1771.

95. A. Binolfi, E. E. Rodriguez, D. Valensin, N. D'Amelio, E. Ippoliti, G. Obal, R. Duran, A. Magistrato, O. Pritsch, M. Zweckstetter, G. Valensin, P. Carloni, L. Quintanar, C. Griesinger, and C. O. Fernandez. Inorg Chem 49 (2010) 10668.

96. M. Bortolus, M. Bisaglia, A. Zoleo, M. Fittipaldi, M. Benfatto, L. Bubacco, and A. L. Maniero. Journal of the American Chemical Society 132 (2010) 18057.

97. P. Davies, X. Y. Wang, C. J. Sarell, A. Drewett, F. Marken, J. H. Viles, and D. R. Brown. Biochemistry 50 (2011) 37.

98. L. Hong, and J. D. Simon. Journal of Physical Chemistry B 113 (2009) 9551.

99. A. Binolfi, R. M. Rasia, C. W. Bertoncini, M. Ceolin, M. Zweckstetter, C. Griesinger, T. M. Jovin, and C. O. Fernandez. J Am Chem Soc 128 (2006) 9893.

100. A. P. Garnett, C. E. Jones, and J. H. Viles. Dalton Trans (2006) 509.

101. E. D. Walter, D. J. Stevens, M. P. Visconte, and G. L. Millhauser. Journal of the American Chemical Society 129 (2007) 15440.

102. M. R. Nilsson. Methods 34 (2004) 151.

103. T. P. Knowles, C. A. Waudby, G. L. Devlin, S. I. Cohen, A. Aguzzi, M. Vendruscolo, E. M. Terentjev, M. E. Welland, and C. M. Dobson. Science 326 (2009) 1533.

104. V. N. Uversky, J. Li, and A. L. Fink. J Biol Chem 276 (2001) 44284.

105. A. M. Morris, M. A. Watzky, J. N. Agar, and R. G. Finke. Biochemistry 47 (2008) 2413.

106. A. I. Bush, W. H. Pettingell, G. Multhaup, M. d Paradis, J. P. Vonsattel, J. F. Gusella, K. Beyreuther, C. L. Masters, and R. E. Tanzi. Science 265 (1994) 1464.

107. C. S. Atwood, R. D. Moir, X. Huang, R. C. Scarpa, N. M. Bacarra, D. M. Romano, M. A. Hartshorn, R. E. Tanzi, and A. I. Bush. J Biol Chem 273 (1998) 12817.

108. X. Huang, C. S. Atwood, R. D. Moir, M. A. Hartshorn, R. E. Tanzi, and A. I. Bush. J Biol Inorg Chem 9 (2004) 954.

109. Y. Yoshiike, K. Tanemura, O. Murayama, T. Akagi, M. Murayama, S. Sato, X. Sun, N. Tanaka, and A. Takashima. J Biol Chem 276 (2001) 32293.

110. B. Raman, T. Ban, K. Yamaguchi, M. Sakai, T. Kawai, H. Naiki, and Y. Goto. J Biol Chem 280 (2005) 16157.

111. C. Ha, J. Ryu, and C. B. Park. Biochemistry 46 (2007) 6118.

112. V. Tougu, A. Karafin, K. Zovo, R. S. Chung, C. Howells, A. K. West, and P. Palumaa. J Neurochem 110 (2009) 1784.

113. M. Innocenti, E. Salvietti, M. Guidotti, A. Casini, S. Bellandi, M. L. Foresti, C. Gabbiani, A. Pozzi, P. Zatta, and L. Messori. J Alzheimers Dis 19 (2010) 1323.

114. J. Ryu, K. Girigoswami, C. Ha, S. H. Ku, and C. B. Park. Biochemistry 47 (2008) 5328.

115. J. T. Pedersen, J. Ostergaard, N. Rozlosnik, B. Gammelgaard, and N. H. Heegaard. J Biol Chem 286 (2011) 26952.

116. S. Jun, J. R. Gillespie, B. K. Shin, and S. Saxena. Biochemistry 48 (2009) 10724.

117. C. Talmard, L. Guilloreau, Y. Coppel, H. Mazarguil, and P. Faller. Chembiochem 8 (2007) 163.

118. P. Hortschansky, V. Schroeckh, T. Christopeit, G. Zandomeneghi, and M. Fandrich. Protein Sci 14 (2005) 1753. 
119. M. Guo, P. M. Gorman, M. Rico, A. Chakrabartty, and D. V. Laurents. FEBS Lett 579 (2005) 3574.

120. G. Meloni, V. Sonois, T. Delaine, L. Guilloreau, A. Gillet, J. Teissie, P. Faller, and M. Vasak. Nat Chem Biol 4 (2008) 366.

121. C. Opazo, X. Huang, R. A. Cherny, R. D. Moir, A. E. Roher, A. R. White, R. Cappai, C. L. Masters, R. E. Tanzi, N. C. Inestrosa, and A. I. Bush. J Biol Chem 277 (2002) 40302.

122. X. Huang, C. S. Atwood, M. A. Hartshorn, G. Multhaup, L. E. Goldstein, R. C. Scarpa, M. P. Cuajungco, D. N. Gray, J. Lim, R. D. Moir, R. E. Tanzi, and A. I. Bush. Biochemistry 38 (1999) 7609.

123. R. Roychaudhuri, M. Yang, M. M. Hoshi, and D. B. Teplow. J Biol Chem 284 (2009) 4749.

124. D. A. Butterfield, T. Reed, S. F. Newman, and R. Sultana. Free Radic Biol Med 43 (2007) 658.

125. B. Halliwell, and J. M. Gutteridge. Biochem J 219 (1984) 1.

126. K. J. Barnham, F. Haeffner, G. D. Ciccotosto, C. C. Curtain, D. Tew, C. Mavros, K. Beyreuther, D. Carrington, C. L. Masters, R. A. Cherny, R. Cappai, and A. I. Bush. Faseb J 18 (2004) 1427.

127. C. Hureau, and P. Faller. Biochimie 91 (2009) 1212.

128. P. N. Lacor, M. C. Buniel, L. Chang, S. J. Fernandez, Y. Gong, K. L. Viola, M. P. Lambert, P. T. Velasco, E. H. Bigio, C. E. Finch, G. A. Krafft, and W. L. Klein. J Neurosci 24 (2004) 10191.

129. D. Noy, I. Solomonov, O. Sinkevich, T. Arad, K. Kjaer, and I. Sagi. J Am Chem Soc 130 (2008) 1376.

130. Y. Miller, B. Ma, and R. Nussinov. Proc Natl Acad Sci U S A 107 (2010) 9490.

131. F. Bousejra-ElGarah, C. Bijani, Y. Coppel, P. Faller, and C. Hureau. Inorganic Chemistry 50 (2011) 9024.

132. D. Valensin, C. Migliorini, G. Valensin, E. Gaggelli, G. La Penna, H. Kozlowski, C. Gabbiani, and L. Messori. Inorganic Chemistry 50 (2011) 6865.

133. W. Garzon-Rodriguez, A. K. Yatsimirsky, and C. G. Glabe. Bioorg Med Chem Lett 9 (1999) 2243.

134. T. Rival, R. M. Page, D. S. Chandraratna, T. J. Sendall, E. Ryder, B. Liu, H. Lewis, T. Rosahl, R. Hider, L. M. Camargo, M. S. Shearman, D. C. Crowther, and D. A. Lomas. Eur J Neurosci 29 (2009) 1335.

135. C. Grossi, S. Francese, A. Casini, M. C. Rosi, I. Luccarini, A. Fiorentini, C. Gabbiani, L. Messori, G. Moneti, and F. Casamenti. J Alzheimers Dis 17 (2009) 423.

136. A. M. Isaacs, D. B. Senn, M. Yuan, J. P. Shine, and B. A. Yankner. J Biol Chem 281 (2006) 27916.

137. A. Ahmad, M. Muzaffar, and V. M. Ingram. Biochim Biophys Acta 1794 (2009) 1537.

138. P. Davies, and D. R. Brown. Biochem J 410 (2008) 237.

139. E. Gaggelli, H. Kozlowski, D. Valensin, and G. Valensin. Chem Rev 106 (2006) 1995.

140. K. Tsiroulnikov, H. Rezaei, M. Dalgalarrondo, J. M. Chobert, J. Grosclaude, and T. Haertle. Biochim Biophys Acta 1764 (2006) 1218.

141. M. A. Wells, C. Jelinska, L. L. Hosszu, C. J. Craven, A. R. Clarke, J. Collinge, J. P. Waltho, and G. S. Jackson. Biochem J 400 (2006) 501.

142. A. K. Thakur, A. K. Srivastava, V. Srinivas, K. V. Chary, and C. M. Rao. J Biol Chem 286 (2011) 38533.

143. E. Quaglio, R. Chiesa, and D. A. Harris. J Biol Chem. 276 (2001) 11432.

144. T. Kuczius, A. Buschmann, W. Zhang, H. Karch, K. Becker, G. Peters, and M. H. Groschup. Biol Chem 385 (2004) 739.

145. K. Qin, D. S. Yang, Y. Yang, M. A. Chishti, L. J. Meng, H. A. Kretzschmar, C. M. Yip, P. E. Fraser, and D. Westaway. J Biol Chem. 275 (2000) 19121. 
146. D. Wu, W. Zhang, Q. Luo, K. Luo, L. Huang, W. Wang, T. Huang, R. Chen, Y. Lin, D. Pang, and G. Xiao. J Cell Biochem 111 (2010) 627.

147. O. V. Bocharova, L. Breydo, V. V. Salnikov, and I. V. Baskakov. Biochemistry 44 (2005) 6776.

148. S. R. Paik, H. J. Shin, J. H. Lee, C. S. Chang, and J. Kim. Biochem J 340 ( Pt 3) (1999) 821.

149. G. Yamin, C. B. Glaser, V. N. Uversky, and A. L. Fink. J Biol Chem 278 (2003) 27630.

150. J. A. Wright, X. Y. Wang, and D. R. Brown. Faseb J 23 (2009) 2384.

151. J. R. Brender, K. Hartman, R. P. Nanga, N. Popovych, R. de la Salud Bea, S. Vivekanandan, E. N. Marsh, and A. Ramamoorthy. J Am Chem Soc 132 (2010) 8973.

152. S. Salamekh, J. R. Brender, S. J. Hyung, R. P. Nanga, S. Vivekanandan, B. T. Ruotolo, and A. Ramamoorthy. J Mol Biol 410 (2011) 294.

153. B. Ward, K. Walker, and C. Exley. J Inorg Biochem 102 (2008) 371.

154. J. S. Valentine, and P. J. Hart. P Natl Acad Sci USA 100 (2003) 3617.

155. J. H. Fox, J. A. Kama, G. Lieberman, R. Chopra, K. Dorsey, V. Chopra, I. Volitakis, R. A. Cherny, A. I. Bush, and S. Hersch. Plos One 2 (2007) e334.

156. J. Herms, T. Tings, S. Gall, A. Madlung, A. Giese, H. Siebert, P. Schurmann, O. Windl, N. Brose, and H. Kretzschmar. J Neurosci 19 (1999) 8866.

157. R. H. Takahashi, T. A. Milner, F. Li, E. E. Nam, M. A. Edgar, H. Yamaguchi, M. F. Beal, H. Xu, P. Greengard, and G. K. Gouras. Am J Pathol 161 (2002) 1869.

158. C. J. Frederickson, J. Y. Koh, and A. I. Bush. Nat Rev Neurosci 6 (2005) 449.

159. P. Paoletti, A. M. Vergnano, B. Barbour, and M. Casado. Neuroscience 158 (2009) 126.

160. Y. H. Hung, A. I. Bush, and R. A. Cherny. J Biol Inorg Chem 15 (2010) 61.

161. G. Danscher, and M. Stoltenberg. J Histochem Cytochem 53 (2005) 141.

162. S. Ueno, M. Tsukamoto, T. Hirano, K. Kikuchi, M. K. Yamada, N. Nishiyama, T. Nagano, N. Matsuki, and Y. Ikegaya. J Cell Biol 158 (2002) 215.

163. K. Vogt, J. Mellor, G. Tong, and R. Nicoll. Neuron 26 (2000) 187.

164. P. Molnar, and J. V. Nadler. Brain Res 910 (2001) 205.

165. M. L. Schlief, A. M. Craig, and J. D. Gitlin. J Neurosci 25 (2005) 239.

166. M. L. Schlief, and J. D. Gitlin. Mol Neurobiol 33 (2006) 81.

167. M. L. Schlief, T. West, A. M. Craig, D. M. Holtzman, and J. D. Gitlin. Proc Natl Acad Sci U S A 103 (2006) 14919.

168. D. E. Hartter, and A. Barnea. Synapse 2 (1988) 412.

169. J. Kardos, I. Kovacs, F. Hajos, M. Kalman, and M. Simonyi. Neurosci Lett 103 (1989) 139.

170. Z. Xiao, and A. G. Wedd. Nat Prod Rep 27 (2010) 768.

171. L. Q. Hatcher, L. Hong, W. D. Bush, T. Carducci, and J. D. Simon. J Phys Chem B 112 (2008) 8160.

172. V. Tougu, A. Karafin, and P. Palumaa. J Neurochem 104 (2008) 1249.

173. C. Vigo-Pelfrey, D. Lee, P. Keim, I. Lieberburg, and D. B. Schenk. J Neurochem 61 (1993) 1965.

174. M. E. Lame, E. E. Chambers, and M. Blatnik. Anal Biochem 419 (2011) 133.

175. C. Talmard, A. Bouzan, and P. Faller. Biochemistry 46 (2007) 13658.

176. P. Davies, F. Marken, S. Salter, and D. R. Brown. Biochemistry 48 (2009) 2610.

177. B. S. Wong, S. G. Chen, M. Colucci, Z. Xie, T. Pan, T. Liu, R. Li, P. Gambetti, M. S. Sy, and D. R. Brown. J Neurochem. 78 (2001) 1400.

178. D. R. Brown, R. S. Nicholas, and L. Canevari. J Neurosci Res 67 (2002) 211.

179. Y. Uchida, F. Gomi, T. Masumizu, and Y. Miura. J Biol Chem 277 (2002) 32353.

180. S. Tsuji, H. Kobayashi, Y. Uchida, Y. Ihara, and T. Miyatake. EMBO J 11 (1992) 4843. 
181. J. C. Erickson, A. K. Sewell, L. T. Jensen, D. R. Winge, and R. D. Palmiter. Brain Res 649 (1994) 297.

182. J. Lauren, D. A. Gimbel, H. B. Nygaard, J. W. Gilbert, and S. M. Strittmatter. Nature 457 (2009) 1128.

183. D. B. Freir, A. J. Nicoll, I. Klyubin, S. Panico, J. M. Mc Donald, E. Risse, E. A. Asante, M. A. Farrow, R. B. Sessions, H. R. Saibil, A. R. Clarke, M. J. Rowan, D. M. Walsh, and J. Collinge. Nat Commun 2 (2011) 336.

184. D. A. Gimbel, H. B. Nygaard, E. E. Coffey, E. C. Gunther, J. Lauren, Z. A. Gimbel, and S. M. Strittmatter. J Neurosci 30 (2010) 6367.

185. E. C. Gunther, and S. M. Strittmatter. J Mol Med (Berl) 88 (2010) 331.

186. S. Chen, S. P. Yadav, and W. K. Surewicz. J Biol Chem 285 (2010) 26377.

187. H. Khosravani, Y. Zhang, S. Tsutsui, S. Hameed, C. Altier, J. Hamid, L. Chen, M. Villemaire, Z. Ali, F. R. Jirik, and G. W. Zamponi. J Cell Biol 181 (2008) 551.

188. R. Sanokawa-Akakura, W. Cao, K. Allan, K. Patel, A. Ganesh, G. Heiman, R. Burke, F. W. Kemp, J. D. Bogden, J. Camakaris, R. B. Birge, and M. Konsolaki. Plos One 5 (2010) e8626.

189. D. L. Sparks, and B. G. Schreurs. Proc Natl Acad Sci U S A 100 (2003) 11065.

190. A. L. Phinney, B. Drisaldi, S. D. Schmidt, S. Lugowski, V. Coronado, Y. Liang, P. Horne, J. Yang, J. Sekoulidis, J. Coomaraswamy, M. A. Chishti, D. W. Cox, P. M. Mathews, R. A. Nixon, G. A. Carlson, P. St George-Hyslop, and D. Westaway. Proc Natl Acad Sci U S A 100 (2003) 14193.

191. T. A. Bayer, S. Schafer, A. Simons, A. Kemmling, T. Kamer, R. Tepest, A. Eckert, K. Schussel, O. Eikenberg, C. Sturchler-Pierrat, D. Abramowski, M. Staufenbiel, and G. Multhaup. Proc Natl Acad Sci U S A 100 (2003) 14187.

192. P. J. Crouch, L. W. Hung, P. A. Adlard, M. Cortes, V. Lal, G. Filiz, K. A. Perez, M. Nurjono, A. Caragounis, T. Du, K. Laughton, I. Volitakis, A. I. Bush, Q. X. Li, C. L. Masters, R. Cappai, R. A. Cherny, P. S. Donnelly, A. R. White, and K. J. Barnham. Proc Natl Acad Sci U S A 106 (2009) 381.

193. J. Shearer, and V. A. Szalai. Journal of the American Chemical Society 130 (2008) 17826.

194. P. Faller. Free Radic Biol Med 52 (2012) 747.

195. S. A. James, I. Volitakis, P. A. Adlard, J. A. Duce, C. L. Masters, R. A. Cherny, and A. I. Bush. Free Radic Biol Med 52 (2012) 298.

196. J. Y. Lee, T. B. Cole, R. D. Palmiter, S. W. Suh, and J. Y. Koh. Proc Natl Acad Sci U S A 99 (2002) 7705.

197. Y. Friedman-Levi, Z. Meiner, T. Canello, K. Frid, G. G. Kovacs, H. Budka, D. Avrahami, and R. Gabizon. Plos Pathog 7 (2011).

198. M. J. Pushie, I. J. Pickering, G. R. Martin, S. Tsutsui, F. R. Jirik, and G. N. George. Metallomics 3 (2011) 206.

199. M. F. Jobling, X. Huang, L. R. Stewart, K. J. Barnham, C. Curtain, I. Volitakis, M. Perugini, A. R. White, R. A. Cherny, C. L. Masters, C. J. Barrow, S. J. Collins, A. I. Bush, and R. Cappai. Biochemistry 40 (2001) 8073.

200. D. R. Brown, B. Schmidt, and H. A. Kretzschmar. Nature 380 (1996) 345.

201. D. J. Stevens, E. D. Walter, A. Rodriguez, D. Draper, P. Davies, D. R. Brown, and G. L. Millhauser. Plos Pathog 5 (2009) e1000390.

202. J. R. Requena, D. Groth, G. Legname, E. R. Stadtman, S. B. Prusiner, and R. L. Levine. Proc Natl Acad Sci U S A. 98 (2001) 7170.

203. E. M. Sigurdsson, D. R. Brown, M. A. Alim, H. Scholtzova, R. Carp, H. C. Meeker, F. Prelli, B. Frangione, and T. Wisniewski. J Biol Chem (2003).

204. J. M. Gorell, C. C. Johnson, B. A. Rybicki, E. L. Peterson, G. X. Kortsha, G. G. Brown, and R. J. Richardson. Neurotoxicology 20 (1999) 239. 
